\title{
High-resolution isotope stratigraphy of the Lower Ordovician St. George Group of western Newfoundland, Canada: implications for global correlation
}

\author{
Karem Azmy and Denis Lavoie
}

\begin{abstract}
The Lower Ordovician St. George Group of western Newfoundland consists mainly of shallow-marine-platform carbonates ( $\sim 500 \mathrm{~m}$ thick). It is formed, from bottom to top, of the Watts Bight, Boat Harbour, Catoche, and Aguathuna formations. The top boundary of the group is marked by the regional St. George Unconformity. Outcrops and a few cores from western Newfoundland were sampled at high resolution and the extracted micritic materials were investigated for their petrographic and geochemical criteria to evaluate their degree of preservation. The $\delta^{13} \mathrm{C}$ and $\delta^{18} \mathrm{O}$ values of wellpreserved micrite microsamples range from $-4.2 \%$ to $0 \%$ (VPDB) and from $-11.3 \%$ to $-2.9 \%$ (VPDB), respectively. The $\delta^{13} \mathrm{C}_{\text {carb }}$ profile of the St. George Group carbonates reveals several negative shifts, which vary between $\sim 2 \%$ and $3 \%$ and are generally associated with unconformities-disconformities or thin shale interbeds, thus reflecting the effect of or link with significant sea-level changes. The St. George Unconformity is associated with a negative $\delta^{13} \mathrm{C}_{\text {carb }}$ shift $(\sim 2 \%)$ on the profile and correlated with major lowstand (around the end of Arenig) on the local sea-level reconstruction and also on those from the Baltic region and central Australia, thus suggesting that the St. George Group Unconformity might have likely had an eustatic component that contributed to the development-enhancement of the paleomargin. Other similar $\delta^{13} \mathrm{C}_{\text {carb }}$ shifts have been recorded on the St. George profile, but it is hard to evaluate their global extension due to the low resolution of the documented global Lower Ordovician (Tremadoc - middle Arenig) $\delta^{13} \mathrm{C}_{\text {carb }}$ profile.

Résumé : Le Groupe de St. George (Ordovicien inférieur) de l'ouest de Terre-Neuve comprend surtout des carbonates de plate-forme marine peu profonde (épaisseur $\sim 500 \mathrm{~m}$ ). De la base au sommet, il comprend les formations suivantes : Watts Bight, Boat Harbour, Catoche et Aguathuna. La limite supérieure du groupe est marquée par la discordance régionale de St. George. Des affleurements et quelques carottes provenant de l'ouest de Terre-Neuve ont été échantillonnés à haute résolution et les roches micritiques extraites ont été étudiées pour leurs critères pétrographiques et géochimiques afin d'évaluer leur degré de préservation. Les valeurs $\delta^{13} \mathrm{C}$ et $\delta^{18} \mathrm{O}$ de micro-échantillons de micrites bien préservées variaient respectivement entre $-4,2 \%$ à $0 \%$ « VPDB » et entre $-11,3 \%$ à $-2,9 \%$ (VPDB). Le profil $\delta^{13} \mathrm{C}_{\text {carb }}$ des carbonates du Groupe de St. George montre plusieurs changements à des valeurs négatives; ces changements varient entre 2\%o à $3 \%$ et ils sont généralement associés à des discordances ou à de minces interlits de shale, reflétant ainsi l'effet des changements importants de niveau de la mer ou ayant un lien avec ces changements. La discordance de St. George est associée à un changement négatif $\delta^{13} \mathrm{C}_{\text {carb }}(\sim 2 \%)$ du profil et elle est corrélée à un important bas niveau dans une reconstruction locale du niveau de la mer (vers la fin de l'Arenigien) ainsi qu'à des bas niveaux dans des régions de la Baltique et du centre de l'Australie, portant ainsi à croire que la discordance du Groupe de St. George avait une composante eustatique qui a contribué au développement - rehaussement de la paléobordure.
\end{abstract}

[Traduit par la Rédaction]

\section{Introduction}

The stable isotope signatures encrypted in preserved marine carbonates have been successfully utilized to understand the evolution of the Earth's system and correlation of sedi-

Received 11 March 2009. Accepted 30 June 2009. Published on the NRC Research Press Web site at cjes.nrc.ca on 7 August 2009.

Paper handled by Associate Editor G. Dix.

K. Azmy. ${ }^{1}$ Department of Earth Sciences, Memorial University of Newfoundland, St. John's, NL A1B 3X5 Canada.

D. Lavoie. Geological Survey of Canada, GSC-Q, Natural

Resources Canada, 490 de la Couronne, Quebec, QC G1K 9A9, Canada.

${ }^{1}$ Corresponding author (e-mail: kazmy@mun.ca). mentary sequences from different depositional settings and paleolandmasses (e.g., Veizer et al. 1999; Halverson et al. 2005; Immenhauser et al. 2008). For some successions, the lack of high-resolution biostratigraphy makes chemostratigraphy a potential tool for refining correlations. The reconstructed isotope profiles, particularly those of carbon isotopes, can be also used for better understanding geological processes and paleo-oceanographic events (e.g., Veizer et al. 1999).

Sea-level changes at the southern shallow-marine paleomargin of Laurentia during the Early Ordovician likely had an impact on organic productivity and oxidation of buried organic matter at the lower margin, which was reflected particularly in the $\mathrm{C}$-isotopic composition of the deposited marine carbonates. The low-resolution of the global Early Ordovician carbon-isotope profile (cf. Qing and Veizer 
Fig. 1. Map showing the approximate locations of the study areas in western Newfoundland, Canada (modified from Zhang et al. 2004).

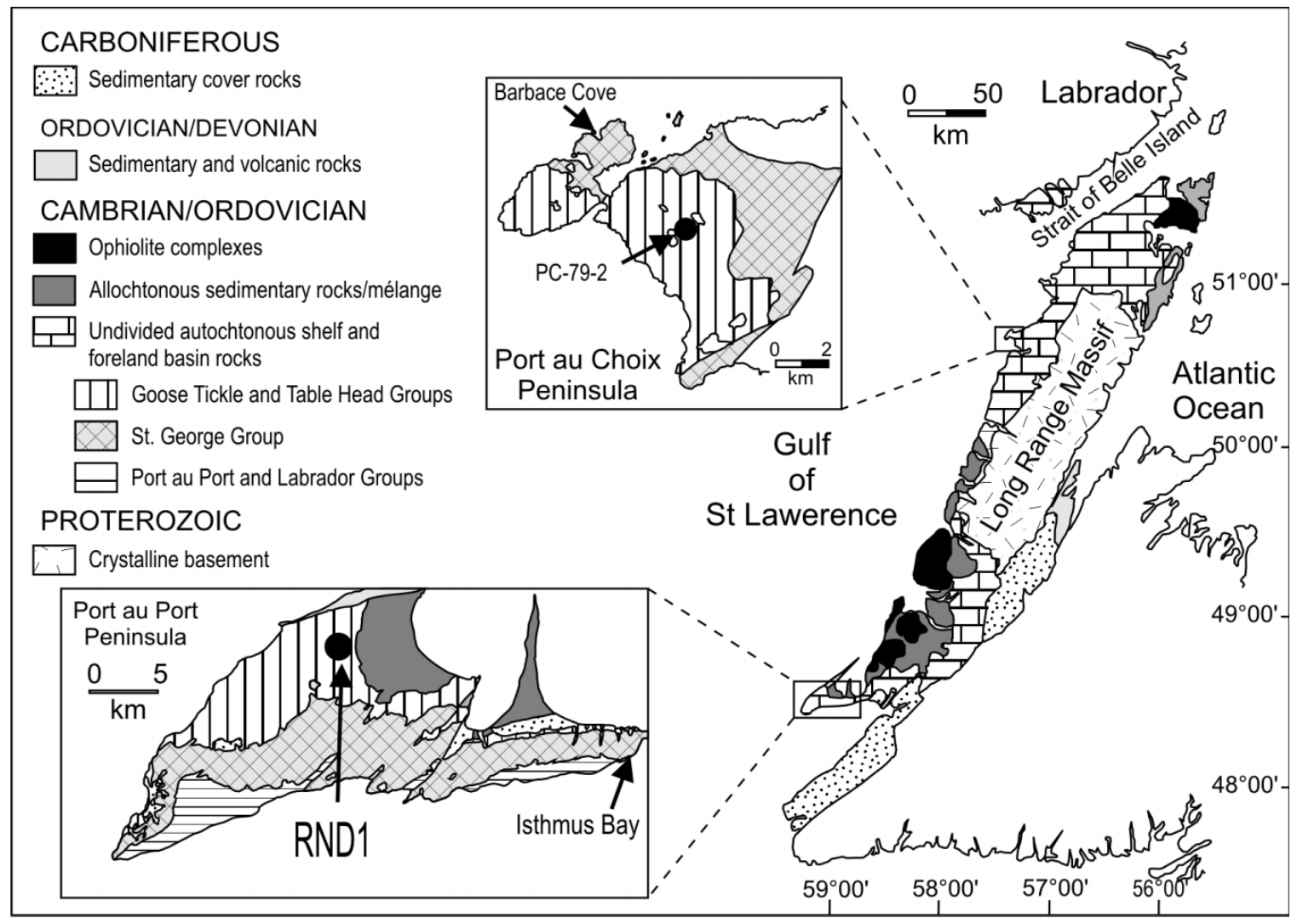

Table 1. Summary of the lithostratigraphy of the St. George Group, Newfoundland. Detailed description in Knight et al. (2007, 2008).

\begin{tabular}{ll}
\hline Formation & Lithology \\
\hline Aguathuna & $\sim 70 \mathrm{~m}$ thick; dolomitized peritidal carbonates; burrow mottled dolostone, dolomicrite, and stromatolitic \\
& dolostones; rare thin shale beds; skeletal peloidal, oolitic and oncolitic grainstones; peloidal wackestones and \\
packstones; microbial (stromatolitic) lime mudstones & \\
Catoche & Up to $160 \mathrm{~m}$ thick; mainly limestones in the lower part $(\sim 120 \mathrm{~m})$ and dolostones in the upper part \\
& $(\sim 40 \mathrm{~m}) ;$ bedded gray carbonates; bioturbated at times; skeletal garinstone to peloidal wackestone and a \\
packstone; microbial lime mudstones & \\
Boat Harbour & Up to $170 \mathrm{~m}$ thick; lower member $(\sim 44 \mathrm{~m})$ of partially dolomitized grainstones, wackestones, thrombolites, and \\
& laminated microbial mats; mainly microbial lime mustone and stromatolitic mounds but rarely grainstones in the \\
& middle member $(\sim 70 \mathrm{~m})$ between the lower disconformity and the overlying Boat Harbour disconformity; peloidal \\
& grainstone to microbial lime mudstones in the upper member $(\sim 52 \mathrm{~m}$, Barbace Cove Member $)$ \\
Watts Bight & $\sim 70 \mathrm{~m}$ thick; partially dolomitized microbial lime mudstone in the lower part $(\sim 33 \mathrm{~m}) ;$ burrowed grainstone in the \\
& middle part $(\sim 25 \mathrm{~m}) ;$ microbial lime mudstone in the upper part $(\sim 11 \mathrm{~m})$
\end{tabular}

1994; Veizer et al. 1999; Shields et al. 2003) makes the high-resolution $\delta^{13} \mathrm{C}$ variations of the investigated St. George Group carbonates a potential reliable database for the reconstruction of a refined regional (Laurentian) profile, which might also allow for possible global correlation (cf. Immenhauser et al. 2008; Bergström et al. 2009).

In the current study, we investigate the major $\delta^{13} \mathrm{C}$ variations in the St. George Group carbonates (Lower Ordovician, Tremadoc - early Arenig) in an attempt to establish a reliable C-isotope stratigraphic profile, which could be utilized for high-resolution correlations in the area and possibly beyond.

\section{Geologic setting}

The lower Paleozoic sediments in western Newfoundland (Fig. 1) were intensively affected by complex orogenic events. The Laurentian plate broke from Rodinia through an active rifting event $\sim 570-550 \mathrm{Ma}$ (Cawood et al. 2001). After rifting, in Early Cambrian, a preplatform shelf developed and was later covered by clastics (James et al. 1989). As the continental margin was slowly established during an early drift episode, a major sea transgression flooded the Laurentia margin and resulted in a thick carbonate-platform succession (Wilson et al. 1992; Knight et al. 2007, 2008 and references therein). During Middle to Late Cambrian, the platform deposits were dominated by high-energy carbonates of the Port au Port Group. These carbonates evolved into the Early to earliest Middle Ordovician low-energy carbonates of the St. George Group (cf. Knight et al. 2007, 2008). Lithospheric depressions from sediment surcharge in Taconian fore arcs resulted in distal lithospheric upwarding and 
Fig. 2. Diagram showing the stratigraphic framework of the St. George Group (after Knight et al. 2007, 2008), sea-level changes in the Laurentian Basin during the deposition of investigated sequence (Early to early Middle Ordovician), and the biozonation scheme (modified from Boyce and Stouge 1997; Zhang and Barnes 2004).

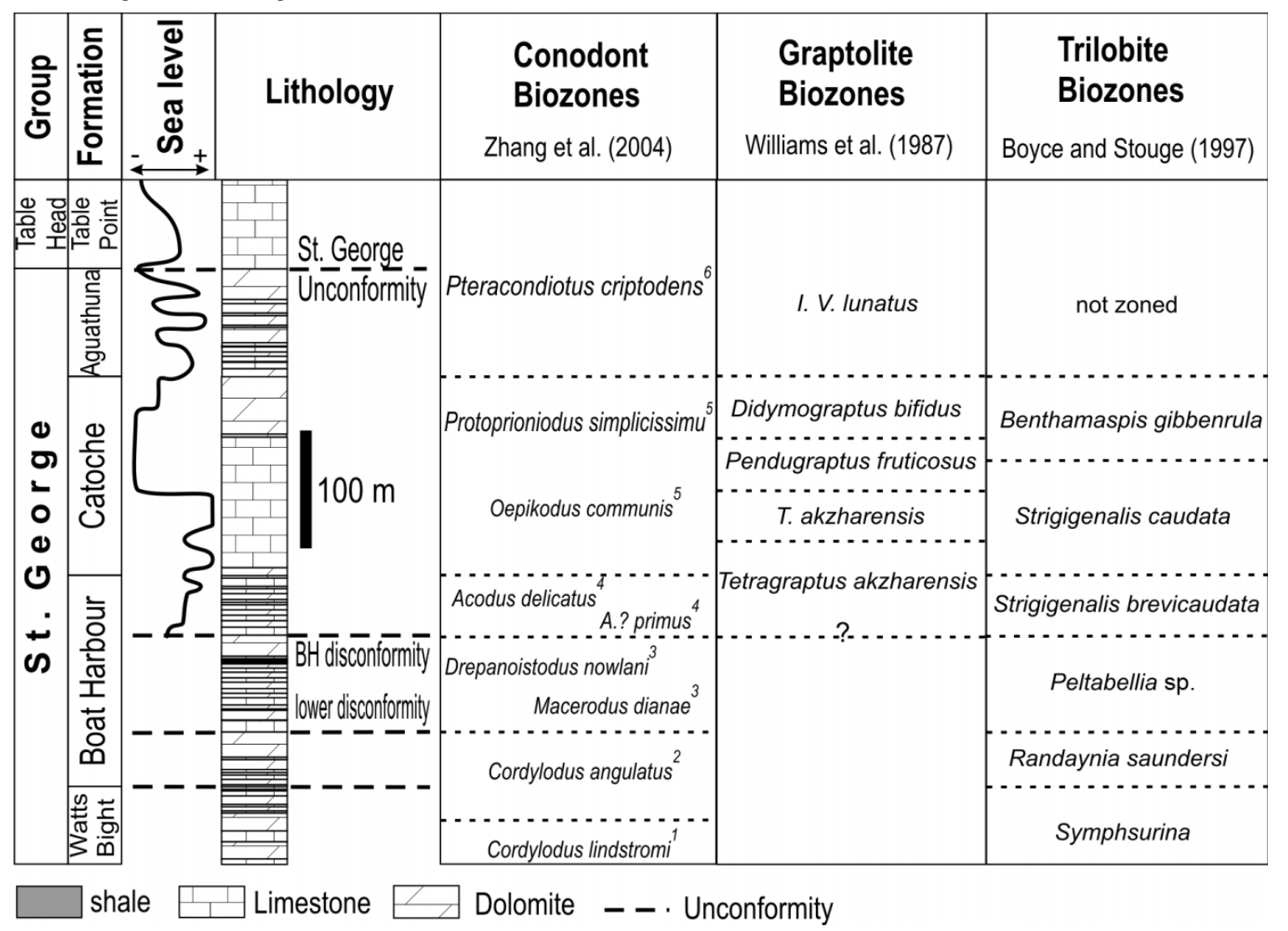

rapid sweeping of a tectonic peripheral bulge on the margin in earliest Middle Ordovician (Jacobi 1981; Knight et al. 1991). The migration of that lithospheric high led to compression, block faulting, uplift, and erosion of the St. George carbonate platform and the development of the regional St. George Unconformity, which leaves the first physical imprint of the transition from a passive margin to a foreland basin (Mussman and Read 1986; Knight et al. 1991, 2007; Lavoie 1994; Cooper et al. 2001). The transition was thus associated with regional tectonic instability that overlapped with falling sea level. The interplay of tectonism and eustatic sea-level changes was assumed to be responsible for the relative sea-level fall and the development of the St. George Unconformity (Knight et al. 1991). A later tectonically driven local sea-level rise accommodated the deposition of the younger Table Head Group (Stenzel et al. 1990; Knight et al. 1991, 2007).

\section{Lithostratigraphy and biostratigraphy}

Lower Paleozoic successions deposited on Laurentia shallow-marine-platform margin are characterized by a thick Middle Cambrian to lower Middle Ordovician carbonate bank. The lithostratigraphy of the St. George Group has been documented, discussed in detail, and refined by several authors (e.g., Pratt and James 1986; Knight and James 1987; Knight 1991; Baker and Knight 1993; Cooper et al. 2001;
Knight et al. 2007, 2008). The lithostratigraphic framework is briefly summarized in Table 1, since the current investigation is mainly focused on the chemostratigraphy of the group. The St. George Group consists of Early Ordovician (Tremadoc-Arenig) platform carbonates $(500 \mathrm{~m}$ thick), which, from bottom to top, include the Watts Bight, Boat Harbour, Catoche, and Aguathuna formations (Table 1). The upper boundary of the St. George Group (Aguathuna Table Point formations contact) is marked by the major regional St. George Group Unconformity (Fig. 2). The St. George Group can be divided into two sedimentary megacycles separated by the Boat Harbour Disconformity (Fig. 2). Each megacycle is characterized by a large-scale transgressive-regressive succession that resulted in stacking of lower peritidal, middle subtidal, and upper peritidal units (Knight and James 1987; Knight et al. 2007, 2008). The Boat Harbour Formation is divided into three members separated by two disconformities (Knight et al. 2008), the stratigraphically higher Boat Harbour Disconformity and an unnamed lower disconformity (Fig. 2). Both disconformities are associated with paleokarst and marked by micro and macro faunal changes (Knight and James 1987; Knight 1991; Ji and Barnes 1993; Boyce and Stouge 1997; Knight et al. 2007, 2008). The upper member, the Barbace Cove Member (Knight and James 1987; Knight 1991), is the initial part of an Arenig transgressive event that onlapped the upper disconformity at a time of global eustatic sea-level rise onto and across the Laurentian margin (upper mega- 
Table 2. Summary of statistics of isotopic and trace element geochemical compositions of the investigated St. George Group carbonates.

\begin{tabular}{|c|c|c|c|c|c|c|c|c|c|c|c|}
\hline & $\mathrm{CaCO}_{3} \%$ & $\mathrm{MgCO}_{3} \%$ & $\mathrm{Mn}(\mathrm{ppm})$ & $\mathrm{Sr}(\mathrm{ppm})$ & $\delta^{18} \mathrm{O} \%$ о VPDB & $\delta^{13} \mathrm{C} \%$ VPDB & $\delta^{13} \mathrm{C}_{\text {organic }} \%$ VPDB & TOC $(\%)$ & $\Delta \delta$ & Carbonate $(\%)$ & $\mathrm{Mn} / \mathrm{Sr}$ \\
\hline \multicolumn{12}{|l|}{ All formations } \\
\hline$n$ & 95 & 95 & 95 & 95 & 167 & 167 & 100 & 100 & 98 & 98 & 95 \\
\hline Average & 79.3 & 20.7 & 170 & 220 & -6.9 & -1.7 & -27.6 & 0.3 & 26.0 & 93.0 & 1.38 \\
\hline Standard deviation & 18.4 & 18.4 & 169 & 130 & 1.7 & 0.8 & 2.2 & 0.5 & 2.5 & 7.2 & 1.62 \\
\hline Maximum & 99.4 & 47.1 & 836 & 653 & -2.9 & 0.0 & -22.1 & 3.3 & 35.0 & 99.7 & 7.72 \\
\hline Minimum & 52.9 & 0.6 & 26 & 27 & -11.3 & -4.2 & -35.1 & 0.0 & 19.7 & 46.1 & 0.08 \\
\hline \multicolumn{12}{|l|}{ Aguathuna } \\
\hline$n$ & 23 & 23 & 23 & 23 & 38 & 38 & 22 & 22 & 22 & 22 & 23 \\
\hline Average & 70.4 & 29.6 & 232 & 164 & -4.9 & -1.5 & -27.7 & 0.1 & 26.2 & 92.9 & 2.35 \\
\hline Standard deviation & 21.0 & 21.0 & 220 & 134 & 1.5 & 0.6 & 1.0 & 0.1 & 1.0 & 6.5 & 2.32 \\
\hline Maximum & 99.4 & 47.0 & 836 & 653 & -2.9 & -0.4 & -25.7 & 0.7 & 28.0 & 99.7 & 7.72 \\
\hline Minimum & 53.0 & 0.6 & 26 & 66 & -8.0 & -3.1 & -29.7 & 0.0 & 24.2 & 75.8 & 0.08 \\
\hline \multicolumn{12}{|l|}{ Catoche } \\
\hline$n$ & 19 & 19 & 19 & 19 & 42 & 42 & 21 & 21 & 21 & 20 & 19 \\
\hline Average & 81.1 & 18.9 & 85 & 220 & -8.5 & -1.6 & -28.6 & 0.1 & 27.0 & 93.6 & 1.36 \\
\hline Standard deviation & 20.1 & 20.1 & 46 & 155 & 0.8 & 0.9 & 1.7 & 0.2 & 2.3 & 6.3 & 1.61 \\
\hline Maximum & 98.9 & 47.1 & 178 & 420 & -6.7 & 0.0 & -26.4 & 0.9 & 35.0 & 99.7 & 4.66 \\
\hline Minimum & 52.9 & 1.1 & 31 & 33 & -11.2 & -3.2 & -35.0 & 0.0 & 23.8 & 76.4 & 0.08 \\
\hline \multicolumn{12}{|l|}{ Boat Harbour } \\
\hline 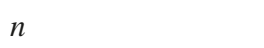 & 26 & 26 & 26 & 26 & 50 & 50 & 30 & 30 & 28 & 29 & 26 \\
\hline Average & 83.3 & 16.7 & 204 & 236 & -6.8 & -2.3 & -26.2 & 0.6 & 23.9 & 92.4 & 1.22 \\
\hline Standard deviation & 12.8 & 12.8 & 162 & 105 & 0.9 & 0.7 & 2.4 & 0.6 & 2.4 & 5.2 & 1.19 \\
\hline Maximum & 99.4 & 31.5 & 715 & 479 & -4.0 & -0.9 & -22.1 & 2.7 & 32.6 & 98.8 & 4.01 \\
\hline Minimum & 68.5 & 0.6 & 38 & 98 & -8.5 & -4.2 & -35.1 & 0.1 & 19.7 & 75.2 & 0.09 \\
\hline \multicolumn{12}{|l|}{ Watts Bight } \\
\hline$n$ & 16 & 16 & 16 & 16 & 23 & 23 & 15 & 15 & 15 & 15 & 16 \\
\hline Average & 74.6 & 25.4 & 75 & 196 & -8.2 & -1.3 & -26.8 & 0.8 & 25.8 & 92.7 & 0.74 \\
\hline Standard deviation & 19.3 & 19.3 & 33 & 120 & 1.4 & 0.4 & 1.8 & 0.7 & 1.6 & 13.0 & 0.70 \\
\hline Maximum & 99.1 & 45.8 & 158 & 390 & -6.0 & -0.6 & -22.2 & 3.3 & 28.2 & 99.1 & 2.32 \\
\hline Minimum & 54.2 & 0.9 & 35 & 27 & -11.3 & -2.2 & -28.6 & 0.1 & 22.2 & 46.1 & 0.09 \\
\hline
\end{tabular}


Fig. 3. A scatter diagram of $\mathrm{Mn} / \mathrm{Sr}$ versus $(a) \delta^{13} \mathrm{C}$ and $(b) \delta^{18} \mathrm{O}$ for the micritic lime mudstone and dolomicrite from the investigated sequences, showing no correlation.
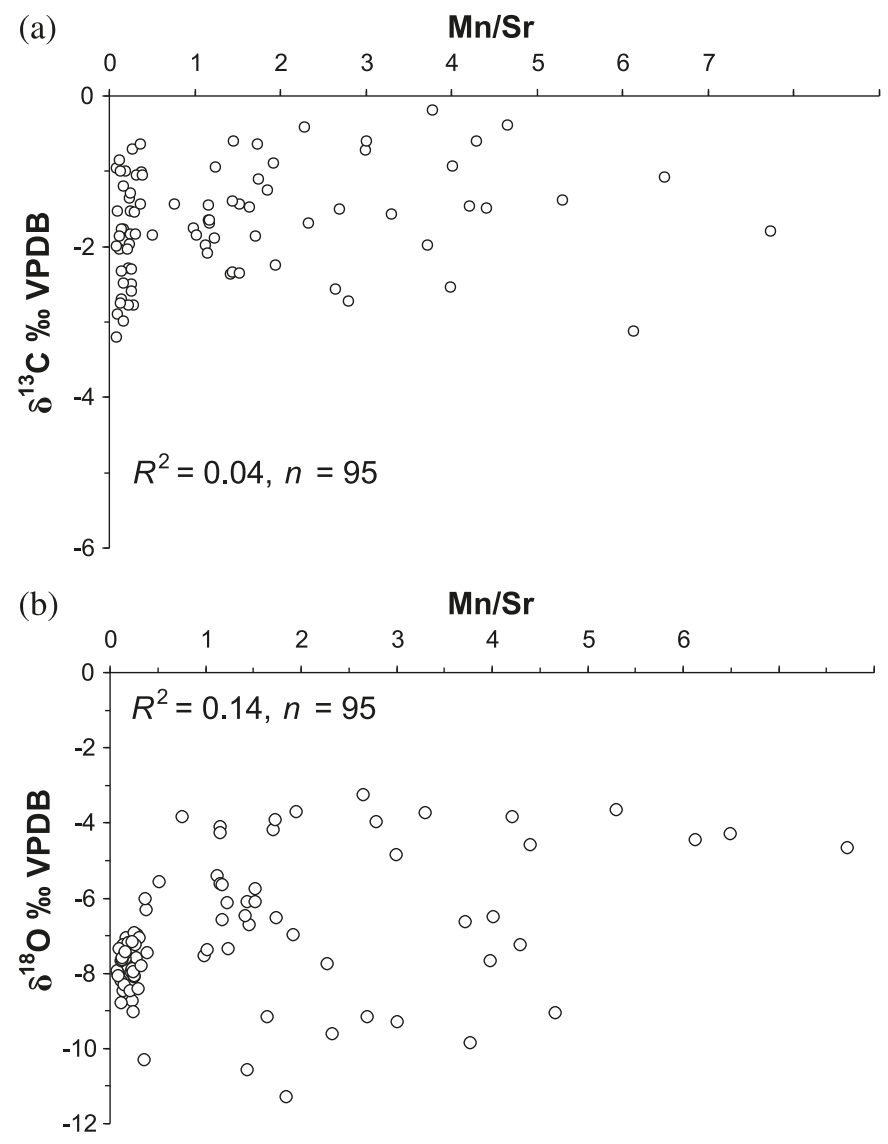

Fig. 4. Oxygen- versus carbon-isotope values for the investigated carbonates, showing insignificant correlations.

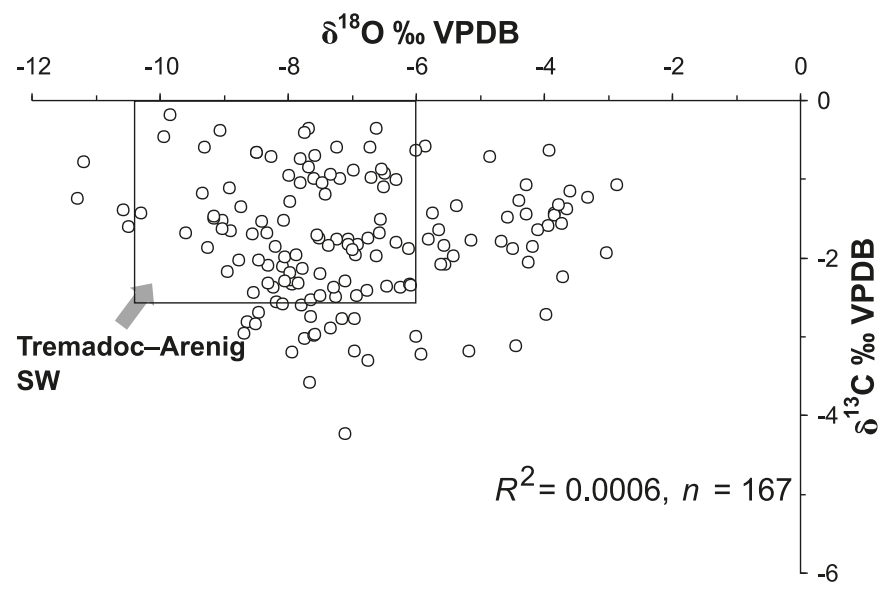

cycle of Knight and James 1987). Multiple-stage dolomitization is relatively abundant in the St. George group carbonates (Knight et al. 2007, 2008; Azmy et al. 2008).

The biostratigraphic framework of the St. George Group has been studied and refined by several authors (e.g., Williams et al. 1987; Boyce and Stouge 1997; Boyce et al. 2000; Zhang and Barnes 2004 and references therein) and is summarized in Fig. 2. The sea-level changes (Fig. 2) reconstructed from the conodont biozonation (cf. Zhang and
Fig. 5. A scatter diagram of $\delta^{13} \mathrm{C}$ versus the total organic carbon contents (TOC; \%) in the studied carbonates.

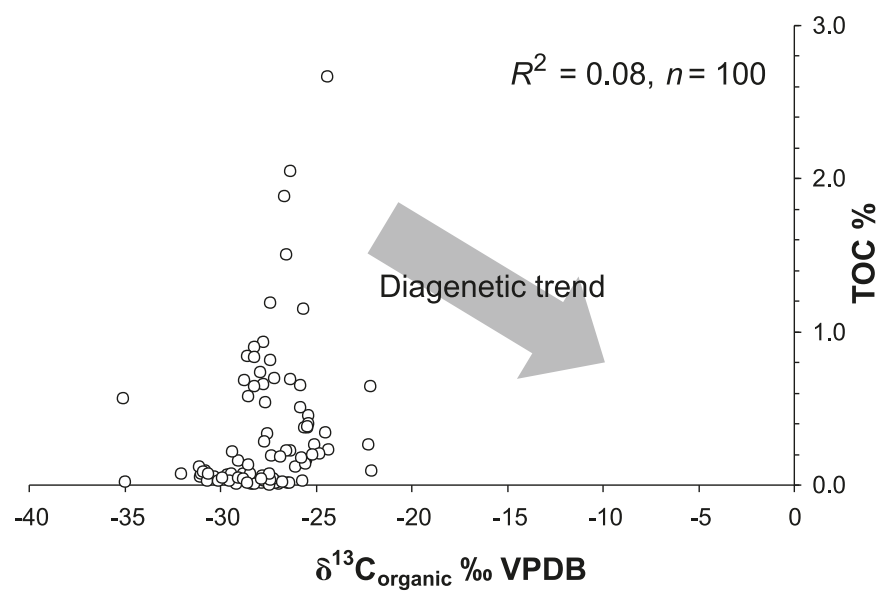

Fig. 6. The $\delta^{13} \mathrm{C}$ values of St. George carbonates versus their carbonate contents.

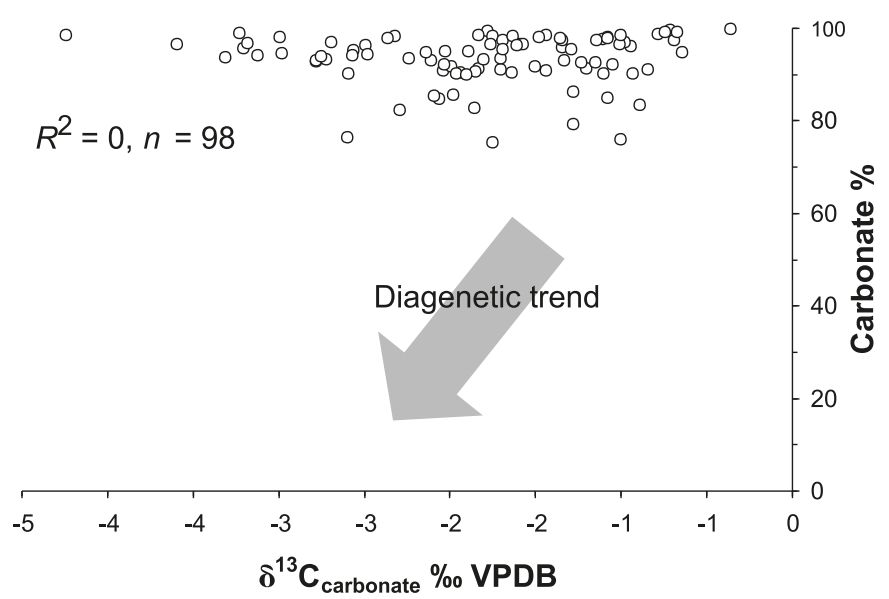

Barnes 2004) cover the upper St. George Group between the uppermost Boat Harbour Formation (Barbace Cove Member) and the lowermost part of the Table Point Formation (Table Head Group) immediately overlying the Aguathuna Formation. However, no reliable reconstructions are known yet to cover the lower part of the St. George Group from the middle member of the Boat Harbour Formation down to the base of Watts Bight Formation (Fig. 2).

The sea-level curve exhibits consistent rises of relatively fast flooding events (Fig. 2), which are correlated, in some cases, with few centimetre thick shale layers overlying thin beds of brecciated carbonates. On the other hand, the same curve shows a drop in sea level at the topmost part of the sequence associated with the regional St. George Unconformity.

\section{Methodology}

Samples were collected at high resolution (sampling interval $\leq 2 \mathrm{~m}$, Appendix A Table A1) from outcrops and cores (Fig. 1) from Port au Port Peninsula and from Port au Choix in western Newfoundland (cf. Knight et al. 2007, 2008; Azmy et al. 2008, 2009; Greene 2008; Conliffe et al. 2009; and more details available at the CISTI, Depository of 
Fig. 7. Correlation of the $\delta^{13} \mathrm{C}_{\text {carb }}$ and $\delta^{13} \mathrm{C}_{\text {org }}$ profiles of the investigated St. George Group (current study) with the global $\delta^{13} \mathrm{C}_{\text {carb }}$ (after Shields et al. 2003; Bergström et al. 2009). The broken line on the global $\delta^{13} \mathrm{C}_{\text {carb }}$ profile represents the mean values documented by Shields et al. (2003) and the width of the grey band represents the $\pm 2 \sigma$ values, whereas the thick black line represents the global values compiled by Bergström et al. (2009) from Buggisch et al. (2003) and Kaljo et al. (2007). The numerical age estimates and chronostratigraphic divisions follow the global scheme after Gradstein et al. (2004) and Bergström et al. (2009). Numbered bars refer to the conodont biozonation scheme as in Fig. 2 and arrows next to letters along the $\delta^{13} \mathrm{C}_{\text {carb }}$ profile point at the most significant events. Legend as in Fig. 2.

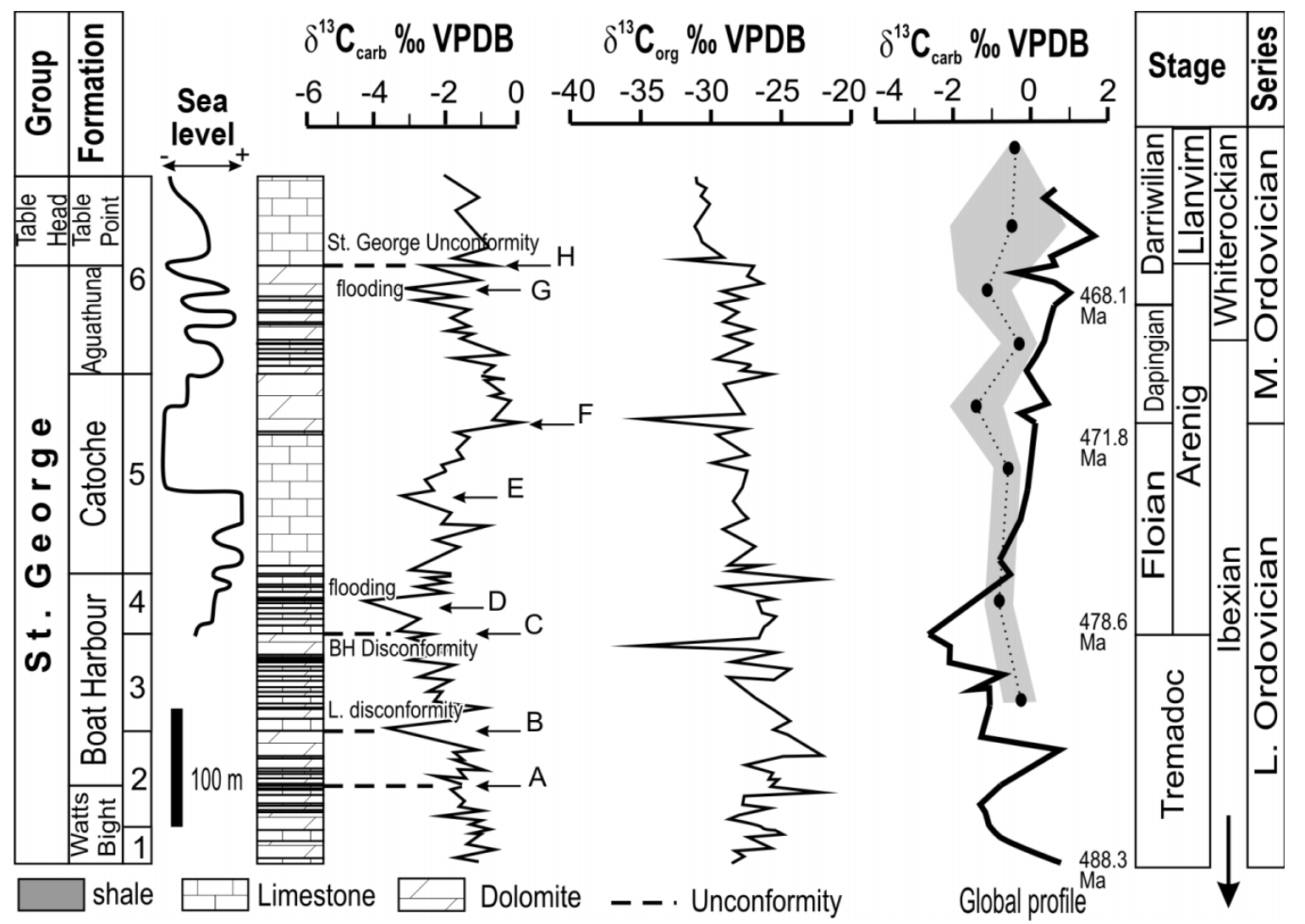

Unpublished Data). The locations of the sampled outcrops and cores are shown in Fig. 1, and the details of the covered intervals with the stratigraphic levels from which the samples were collected are provided in Table A1. The sampled outcrops and cores were carefully selected to cover the maximum thickness of the formations and to avoid tectonic complications.

Thin sections of the samples were examined petrographically with a polarizing microscope and cathodoluminoscope and stained with Alizarin Red-S and potassium ferricyanide solutions. A mirror-image slab of each thin section was also prepared and polished for microsampling. Cathodoluminescence observations were performed using an ELM-3R cold cathode instrument operated at $\sim 12 \mathrm{kV}$ accelerating voltage and $\sim 0.7 \mathrm{~mA}$ gun current intensity.

Polished slabs were washed with deionized water and dried overnight at $50{ }^{\circ} \mathrm{C}$ prior to the isolation of the finest grained micritic lime mudstone and dolomicrites free of cements. Approximately $5 \mathrm{mg}$ were microsampled from the nonluminescent lime mudstone and dolomicrite in cleaned slabs with a low-speed microdrill under a binocular microscope. The geochemical analyses have been mainly carried out on the microsampled carbonate, except for those of the evaluation of carbonate contents and the measurements of $\delta^{13} \mathrm{C}$ of organic carbon that were run on bulk sample powders.
For C- and O-isotope analyses, $\sim 220 \mu \mathrm{g}$ of powder sample was reacted in inert atmosphere with ultrapureconcentrated $(100 \%)$ orthophosphoric acid at $70{ }^{\circ} \mathrm{C}$ in a Thermo-Finnigan Gasbench II and the produced $\mathrm{CO}_{2}$ was automatically delivered to the source of a Thermo-Finnigan DELTA $\mathrm{V}$ plus isotope ratio mass spectrometer in a stream of helium, where the gas was ionized and measured for isotope ratios. Uncertainties of better than $0.1 \%$ ( $2 \sigma)$ for the analyses were determined by repeated measurements of NBS-19 $\left(\delta^{18} \mathrm{O}=-2.20 \%\right.$ and $\delta^{13} \mathrm{C}=+1.95 \%$ versus Vienna PeeDee Belemnite (VPDB)) and L-SVECS $\left(\delta^{18} \mathrm{O}=-26.64 \%\right.$ and $\delta^{13} \mathrm{C}=-46.48 \%$ versus $\left.\mathrm{VPDB}\right)$, as well as internal standards.

For elemental analyses, a subset of sample powder was digested in 5\% ( $/ / v)$ acetic acid for 70-80 min and analyzed for $\mathrm{Ca}, \mathrm{Mg}, \mathrm{Sr}$, and $\mathrm{Mn}$ (Coleman et al. 1989) using a HP 4500 plus at Memorial University of Newfoundland, St. John's, Newfoundland. The relative uncertainties of these measurements are better than 5\%. Calculations are based on $100 \%$ carbonates.

Organic carbon isotope ratios were measured on isolated kerogen, after repeated treatment with concentrated hydrochloric acid at the isotope laboratory of Memorial University of Newfoundland, using a Carlo Erba Elemental Analyzer coupled to a 252 Finnigan MAT mass spectrometer. The re- 
sults were normalized to the standards IAEA-CH-6 $\left(\delta^{13} \mathrm{C}=-10.43 \%\right), \operatorname{NBS} 18\left(\delta^{13} \mathrm{C}=-5.04 \%\right)$, and USGS24 $\left(\delta^{13} \mathrm{C}=-15.99 \%\right)$; and the uncertainty calculated from repeated measurements was $\sim 0.2 \%$.

\section{Results and discussion}

The geochemical attributes of the St. George Group carbonates are described in detail in Table A1 and their statistics are summarized in Table 2. The chemostratigraphic correlations are mainly based on the distinctive variations in the $\delta^{13} \mathrm{C}_{\text {carb }}$ profile of the investigated sequences, which exhibit the $\delta^{13} \mathrm{C}_{\text {carb }}$ variations in preserved micritic carbonates. These variations may reflect environmental or diagenetic perturbations (Table A1). Therefore, the evaluation of the retained geochemical signatures is a cornerstone for the reconstructions of reliable chemostratigraphic profiles.

\section{Evaluation of sample preservation}

Several petrographic and geochemical techniques have been utilized to evaluate the degree of preservation of the studied Lower Ordovician micritic carbonates of the St. George Group (e.g., Azmy et al. 2006). Thin sections were examined using a petrographic microscope for grain size, degree of recrystallization, detrital components, and sedimentary structures. The St. George micritic carbonates exhibit insignificant recrystallization and preservation of primary sedimentary fabrics (e.g., Azmy et al. 2008, 2009). This is also true for many of the dolomitized horizons likely because dolomitization has started at very early stages of diagenesis.

Cathodoluminescence was utilized to study the diagenetic and depositional components and to refine the selection of best preserved carbonates (e.g., Azmy et al. 2001, 2006). Luminescence in carbonates is mainly activated by high concentrations of $\mathrm{Mn}$ and quenched by high concentrations of Fe (Machel and Burton 1991). Bright luminescence indicates diagenetic alteration; but the degree of carbonate luminescence, however, may have to be taken with caution because some altered carbonates might still exhibit no luminescence due to high Fe contents (Rush and Chafetz 1990).

The trace element analyses of the current investigations were obtained from microsamples, which were drilled from the finest grained carbonates. The $\mathrm{Mn}$ and $\mathrm{Sr}$ abundances and $\delta^{18} \mathrm{O}$ of carbonates are significantly modified by alteration under the influence of diagenetic fluids, which results in significant enrichment in Mn contents but depletions in those of $\mathrm{Sr}$ and ${ }^{18} \mathrm{O}$ (Brand and Veizer 1980; Veizer 1983). Therefore, the $\mathrm{Mn} / \mathrm{Sr}$ ratio of marine carbonates is commonly utilized as a tool for evaluating their degree of preservation (e.g., Derry et al. 1992; Kaufman and Knoll 1995). In general, ratios up to 10 (low $\mathrm{Sr}$ contents) have been accepted for $\delta^{13} \mathrm{C}_{\text {carb }}$ studies particularly because the diagenetic fluids, at low water-rock interaction associated with insignificant recrystallization, do not have much $\mathrm{CO}_{2}$ to reset the C-isotopic composition of the carbonates (e.g., Kaufman and Knoll 1995; Corsetti and Kaufman 2003).

The $\mathrm{Mn} / \mathrm{Sr}$ ratios of the investigated dolomicrite and lime mudstones of the St. George Group range from $\sim 0.1$ to 7.7 $(1.38 \pm 1.69, n=95$; Table 2$)$ and $\mathrm{Sr}$ concentrations reach up to $\sim 653 \mathrm{ppm}(220 \pm 130 \mathrm{ppm}, n=95$; Table 2$)$. Some of the lime mudstones may still retain high $\mathrm{Sr}$ contents (>600 ppm) comparable with those of modern marine carbonates (cf. Brand et al. 2003) and thus suggesting a local high degree of preservation. Therefore, the $\delta^{13} \mathrm{C}$ values of most samples may be considered as little altered given the lack of relationship of $\mathrm{Sr}$ contents with $\mathrm{Mn} / \mathrm{Sr}$ ratios (Fig. 3a).

Oxygen-isotope compositions of carbonates are also sensitive monitors of alteration by diagenetic fluids, which are usually ${ }^{18} \mathrm{O}$-depleted relative to seawater. However, the preservation of dominant micritic grain size and retention of sedimentary fabrics of the investigated carbonates may argue against severe diagenetic alteration. Although the $\delta^{18} \mathrm{O}$ values range widely from $-11.3 \%$ to $-2.9 \%$ VPDB (Fig. 3b), suggesting variable degrees of alteration, there is no systematic relationship between the $\mathrm{Mn} / \mathrm{Sr}$ and $\delta^{18} \mathrm{O}$ (Fig. $3 b$ ) or between the $\delta^{18} \mathrm{O}$ and $\delta^{13} \mathrm{C}$ values (Fig. 4). Also, it is noteworthy that the majority of the $\delta^{13} \mathrm{C}$ values of the microsampled micritic limemuds and dolomicrites fall within the documented range of the well-preserved carbonates deposited from the Early to Middle Ordovician seawaters (Veizer et al. 1999; Shields et al. 2003), thus suggesting high degree of preservation of chemical signatures (Fig. 4). The lack of petrographic evidence for significant recrystallization (cf. Banner and Hanson 1990), the absence of any correlation between $\delta^{13} \mathrm{C}$ and $\mathrm{Mn} / \mathrm{Sr}$ values, the comparable $\delta^{13} \mathrm{C}$ values obtained from micritic limestones and dolomicrites from the same layer, and the consistency of $\delta^{13} \mathrm{C}$ values in closely spaced stratigraphic samples (Table A1) support the view that the variations in the $\delta^{13} \mathrm{C}$ values of the St. George Group carbonates may reflect depositional conditions (cf. Kaufman and Knoll 1995; Azmy et al. 2001, 2006).

The $\delta^{13} C_{\text {org }}$ values of organic matter (Table 2), isolated from selected samples (Fig. 5), range from ca. $\sim-35 \%$ to $-22.1 \%$ o $(-27.6 \%$ o $2.2 \%, n=100)$. The Taconian and Acadian deformation affecting western Newfoundland might have resulted in efficient plumbing systems for channelizing very high-temperature fluid flows, which could have led to some metamorphic enrichment of the $\delta^{13} C_{\text {org }}$ in organic matter (cf. Schidlowski et al. 1975; Hayes et al. 1983 , 1999) and affected the $\delta^{13} \mathrm{C}_{\mathrm{carb}}$. However, the lack of correlation between the $\delta^{13} \mathrm{C}_{\text {org }}$ and total organic carbon (TOC) abundance in the studied carbonates (Fig. 5) would argue against any metamorphic influence (e.g., Azmy et al. 2006). The lack of correlation between the $\delta^{13} C_{c a r b}$ values and carbonate abundance in bulk samples (Fig. 6) also argues against the influence of any terrestrial input of organic matter on the $\mathrm{C}$-isotope composition of carbonates.

The absence of abundant bacterial pyrite, pipelike sedimentary structure, or significant depletion in the $\delta^{13} \mathrm{C}$ of the analyzed micritic carbonates dismisses the potential diagenetic influence of the sulfate reducing zone and methanogenesis on the $\delta^{13} \mathrm{C}$ signatures of the studied carbonates (e.g., Patterson and Walter 1994; Dickson et al. 2008). Variations in the value of the $\delta^{13} \mathrm{C}$ excursions in a profile can be influenced by the absolute depth of the epiric seas and the locations of sediment relative to open ocean water due to effect of significance of circulation (e.g., Immenhauser et al. 2008), but the occurrence of some shelly fossils (e.g., brachiopod shell fractions) in the investigated carbonates agues for insignificant variations in water depth. 


\section{St. George Group $\delta^{13} \mathrm{C}$ isotope stratigraphy}

Petrographic observations and geochemical results indicate that the $\delta^{13} \mathrm{C}$ signatures of the investigated St. George Group carbonates are preserved or at least near primary. Thus, the constructed $\delta^{13} \mathrm{C}$ stratigraphic profiles are reliable and depict temporal variations in Early-Middle Ordovician seawater chemistry (Fig. 7).

The $\delta^{13} \mathrm{C}_{\text {carb }}$ profile of the St. George Group carbonates (Fig. 7) reveals some significant negative isotopic excursions, which vary between $\sim 1.5 \%$ and $3.0 \%$. These shifts are correlated with unconformities-disconformities (sea-level lowstands) or thin shale interbeds (interpreted as flooding surfaces), thus reflecting the effect of considerable sea-level changes on the $\delta^{13} \mathrm{C}$ ratios of carbonates. Long-term stratification of oceans (e.g., Zhang et al. 2001) results in shut down of effective oceanic circulation and nutrient flux (e.g., Hotinski et al. 2001; Hoffman and Schrag 2002), which may also develop dramatic depletions in the $\delta^{13} \mathrm{C}$ composition of carbonates. However, the St. George carbonates exhibit no evidence to support such scenario.

The Watts Bight - Boat Harbour formation boundary is marked by an erosion surface; and there are two disconformities within the Boat Harbour Formation itself (Fig. 7), the lower disconformity and the upper Boat Harbour Disconformity (Knight et al. 2008; Azmy et al. 2009; Conliffe et al. 2009). In the upper part of the formation, a $\sim 2 \mathrm{~cm}$ thick shale interbed occurs and is interpreted to have resulted from a brief and rapid sea-level rise (Knight et al. 2008). The C-isotope compositions of the Boat Harbour carbonates $(-2.3 \% \pm 0.7 \%$ VPDB, $n=50$; Table 2$)$ are generally depleted relative to those of the underlying Watts Bight carbonates $\left(-1.3 \% \%_{0} \pm 0.4 \%\right.$ VPDB, $n=23$; Table 2$)$. The $\delta^{13} \mathrm{C}_{\text {carb }}$ profile of the Watts Bight Formation shows generally no significant excursions (Fig. 7) and no significant ${ }^{13} \mathrm{C}_{\text {carb }}$ variation has been recorded at the Watts Bight - Boat Harbour unconformable boundary (A, Fig. 7). This might suggest that the time hiatus physically was possibly small and involved no significant variations in the seawater carbon budget.

On the contrary, the Boat Harbour $\delta^{13} \mathrm{C}_{\text {carb }}$ profile has two negative shifts, one correlated with each of the disconformities, but the shift of the lower disconformity (B, Fig. 7) is larger $(\sim 3 \%)$ than that of the Boat Harbour Diconformity (C, $\sim 1.5 \%$; Fig. 7$)$. Also, a remarkable depletion $(\sim 10 \%$ o followed by quick recovery in the $\delta^{13} \mathrm{C}_{\text {org }}$ in sediments occurs at a stratigraphic level immediately below the Boat Harbour Disconformity (C, Fig. 7) and is correlated with a high $\delta^{13} \mathrm{C}_{\text {carb }}$ value, suggesting a short episode of considerable high organic productivity before the sea-level drop. The drop in sea level, which resulted in the unconformity, might have possibly brought oxygen-rich shallow seawater in contact with organic matter buried and (or) induced the migration of unconformity-related lowstand lens of oxygenated waters in the shallow buried sediments that oxidized organic matter to release ${ }^{12} \mathrm{C}$-rich bicarbonate ions (cf. Holmden et al. 1998; Immenhauser et al. 2008).

The Barbace Cove sediments that overly the Boat Habour Disconformity have been suggested by earlier studies (e.g., Knight and James 1987) to be deposited by a eustatic early Arenigian rise. However, the incomplete sea-level reconstructions covering the time of the Boat Harbour - Watts
Bight interval make it difficult at this stage to speculate on the global extension of the lower Boat Harbour Disconformity sea-level fall.

A third negative $\delta^{13} \mathrm{C}_{\text {carb }}$ shift (D, $\sim 2.2 \%$; Fig. 7) found in the uppermost section (Barbace Cove Member) of the Boat Harbour Formation is correlated with a thin shale layer ( $\sim 2 \mathrm{~cm}$ thick; Knight et al. 2008) overlying a thin bed of brecciated carbonates (minor sedimentary hiatus). A steadily and significant increase in $\delta^{13} \mathrm{C}_{\text {carb }}$ ratios is observed for carbonates that overly the Boat Harbour Formation (Fig. 7). The Catoche Formation carbonates have generally more enriched $\delta^{13} C_{\text {carb }}$ values $(-1.6 \% \pm 0.9 \%$ VPDB, $n=42$; Table 2) compared with their underlying Boat Harbour counterparts $(-2.3 \% 0 \pm 0.7 \%$ VPDB,$n=50$; Table 2$)$, which might reflect a general increase in organic primary productivity in the basin. Unlike the Boat Harbour, the Catoche $\delta^{13} \mathrm{C}_{\text {carb }}$ profile exhibits only one significant negative $\delta^{13} \mathrm{C}_{\text {carb }}$ excursion (E, $\sim 3.2 \%$; Fig. 7) spanning roughly the middle interval of the formation. This shift is correlated with the end of sea-level highstand and the beginning of dramatic sea-level fall (Zhang and Barnes 2004), which is physically expressed in transition from low-energy muddy carbonate lithofacies to high-energy grainstones (Knight et al. 2007; Greene 2008). The lack of a correlated response on the ${ }^{13} \mathrm{C}_{\text {org }}$ profile makes hard to speculate on the mechanism that caused the $\delta^{13} \mathrm{C}_{\text {carb }}$ depletion. On the other hand, sealevel reconstructions (Zhang and Barnes 2004) show a long period of lowstand during most of the upper part of the Catoche Formation with sea-level rise only recorded in the topmost part of the formation (Fig. 7). The $\delta^{13} \mathrm{C}_{\text {carb }}$ profile shows also a positive shift of $\sim 3 \%$ (F, Fig. 7) towards the topmost part of the formation, which occurs at the end of a long-term but slow-paced increase in $\delta^{13} \mathrm{C}_{\text {carb }}$ (Fig. 7). The positive $\delta^{13} \mathrm{C}_{\text {carb }}$ peak (F) is correlated with a significant negative $\delta^{13} \mathrm{C}_{\text {org }}$ shift of $\sim 8 \%$ (Fig. 7). This may suggest a recovery of the marine biota and organic productivity during the overall lowstand and a final acceleration of recovery at the onset of significant flooding over the Catoche peritidal platform leading to more burial of organic carbon (Fig. 7). This is also consistent with the general enrichment in the $\delta^{13} C_{\text {carb }}$ compositions of the Catoche Formation carbonates relative to their underlying counterparts (Table 2).

The Aguathuna Formation carbonates have comparable Cisotope composition $(-1.5 \% \pm 0.6 \%$ VPDB, $n=50$; Table 2$)$ to that of the underlying Catoche carbonates $(-1.6 \% \pm \pm 0.9 \%$ VPDB, $n=42$; Table 2). However, the general $\delta^{13} C_{\text {carb }}$ profile of the Aguathuna carbonates is part of a long-term decreasing trend that started in the upper part of the Catoche Formation, but the values never get to the very negative ratios yielded by the lower units of the St. George (Fig. 7). The Aguathuna $\delta^{13} \mathrm{C}_{\text {carb }}$ profile has two major negative shifts (Fig. 7), one near the top of the formation (G) and the other one that coincides with the level of the regional St. George Unconformity $(\mathrm{H})$, which marks the Aguathuna - Table Point formation boundary (Knight et al. 2007). The near-top negative shift $(\mathrm{G}, \sim 2 \%$; Fig. 7$)$ is associated with a minor disconformity overlain by a thin (few centimetre thick) transgressive shale bed, whereas the topmost boundary shift (H, $\sim 2 \%$; Fig. 7) is correlated with a major sea-level fall during the St. George Unconformity (Fig. 7). The St. George Unconformity is characterized by major subaerial exposure 
that led to meteoric diagenesis and significant karstification of the topmost rocks of the formation (Lane 1990; Knight et al. 1991, 2007; Azmy et al. 2008). The St. George Unconformity negative $\delta^{13} \mathrm{C}_{\text {carb }}$ shift also correlates with a positive $\delta^{13} \mathrm{C}_{\text {org }}$ shift of $\sim 5 \%$ o (Fig. 7 ), thus likely reflecting the effect of oxidation of organic matter during sea-level fall, which brought oxygen-rich shallow seawater and (or) lowstand meteoric water lenses in contact with buried organic matter, which resulted in release of ${ }^{12} \mathrm{C}$-rich $\mathrm{CO}_{2}$ (cf. Holmden et al. 1998; Immenhauser et al. 2008).

\section{Implications for global correlations}

Age uncertainty and low resolution of the global biostratigraphic framework are amongst the main reasons for problems in stable isotope global correlations and paleooceanographic models. The current study uses the most upto-date Early and Middle Ordovician international classifications (Tremadocian, Floian, Dapingian, and Darriwilian; Gradstein et al. 2004; Bergström et al. 2009) alongside the previously used British (Tremadocian, Arenigian, and Llanvirnian) and North American (Ibexian and Whiterockian) stratigraphic stage nomenclatures (cf. Shields et al. 2003; Knight et al. 2007, 2008) in attempt to refine, if possible, the global correlation of the investigated St. George Group sequence (Fig. 7).

The C-isotope compositions of Lower Ordovician carbonates have been investigated in other sedimentary basins (e.g., Holmden et al. 1998; Buggisch et al. 2003; Shields et al. 2003; Kaljo et al. 2007; Bergström et al. 2009) on different landmasses. The global Early Ordovician $\delta^{13} \mathrm{C}_{\text {carb }}$ profile (Bergström et al. 2009 and more references therein) has been mainly reconstructed from complete dataset obtained from basins in Argentina (Buggisch et al. 2003) and Baltoscandia (Kaljo et al. 2007).

Although the sedimentological evidences suggest deposition in warm shallow marine water (epiric seas), the $\delta^{13} \mathrm{C}_{\text {carb }}$ composition of the St. George Group carbonates ( $\sim-4 \%$ to $+1 \%$ VPDB $)$ is slightly lighter than that $(\sim-3 \%$ to $+2 \%$ o VPDB) of the Argentinean and Baltoscandian counterparts (Fig. 7). The petrographic and geochemical criteria of the investigated rocks support high degree of preservation, which dismisses the potential influence of diagenetic alteration. Variations in carbon cycling in sedimentary basins, organic activity, circulation, and distance from open water conditions have been known to play a significant role in controlling the $\delta^{13} \mathrm{C}_{\text {carb }}$ of marine carbonates (Azmy et al. 1998; Kump and Arthur 1999; Holmden et al. 1998; Veizer et al. 1999; Immenhauser et al. 2008). Sediments of the inner epiric environment are deposited in water masses of little exchanges with open sea compared with those deposited in more outward settings closer to open-water marine circulation and exchanges. This may influence the input of nutrients and organic matter through terrestrial input and also upwelling, which will likely control the $\delta^{13} C_{\text {carb values (e.g., }}$ Holmden et al. 1998; Calver 2000; Immenhauser et al. 2008). Also, expansion and contraction of epicontinental water masses (e.g., sea-level changes) by local tectonic activities might result in some variable ${ }^{13} \mathrm{C}_{\mathrm{carb}}$ excursions in the $\mathrm{C}$-isotope profile of a particular sedimentary basin despite the absence of global-scale changes in the Earth's ocean system during that time (e.g., Holmden et al. 1998).
The profile shows negative shifts (Fig. 7), each of $\sim 2 \%$, which are possibly comparable to those on the St. George profile. The global mid-Tremadocian shift can be correlated with the negative shift (B) on the local profile and with the lower Boat Harbour Disconformity. Also, the global shift at the Tremadocian-Floian boundary can be correlated to the local shift (D), taking into consideration the uncertainty in the stratigraphic position of the biozone boundaries. On the other hand, a global positive $\delta^{13} \mathrm{C}_{\text {carb }}$ excursion $(\sim 3.5 \%$ ) reaches its maximium around the Floian-Dapingian boundary and can be correlated the positive shift (F) on the St. George profile ( $\sim \%$; Fig. 7 ).

The St. George Group $\delta^{13} \mathrm{C}_{\text {carb }}$ profile shows several negative excursions (A-H, Fig. 7) that are herein correlated with sea-level changes along the Laurentian margin. Although sea-level reconstructions for the Early Ordovician from eastern Laurentia (Zhang and Barnes 2004), Baltic region, and central Australia (Nielsen 1992a, 1992b) exhibit slight differences (cf. Zhang and Barnes 2004), they all agree on a major sea-level lowstand near the end of Arenig. Along the paleosouthern margin of Laurentia, this unconformity (with local nomenclature) extends from southeastern USA (Mussman and Read 1986) to southern Quebec (Salad Hersi et al. 2007; Lavoie et al. in press) to Anticosti (Desrochers et al. in press) and as far as eastern Greenland (Boyce and Stouge 1997; Knight et al. 2007). At the large scale, the global negative $\delta^{13} \mathrm{C}_{\text {carb }}$ shift around the lowermost Darriwilian (uppermost Arenig) coincides biostratigraphically with the St. George Unconformity in western Newfoundland and its associated negative $\delta^{13} \mathrm{C}_{\text {carb }}$ shift $(\mathrm{H}$, $\sim 2 \%$; Fig. 7). This is also consistent with the profile of Shields et al. (2003), which is based on data from Utah and Oklahoma. However, it has shown that the development of the lower Middle Ordovician unconformity in western Newfoundland (Knight et al. 1991) and its nearby areas (Salad Hersi et al. 2007) had a significant tectonic component related to ongoing subduction in the Iapetus Ocean near Laurentia. Very fine-scale, combined palynology and $\delta^{13} \mathrm{C}_{\text {carb }}$ studies could eventually generate data on fine-scale diachroneity of the isotopic shift and epilogue on the tectonic-eustatic relative contributions to the development of the unconformity and related isotopic shift.

In summary, although the local $\delta^{13} \mathrm{C}_{\text {carb }}$ profile of western Newfoundland has several excursions, only a few of them can be potentially correlated with comparable shifts on the global counterpart. The remaining excursions are most likely local and related to changes in the depositional environment of the western Newfoundland Lower-Middle Ordovician platform at the margin of Laurentia.

\section{Conclusions}

Petrographic and geochemical investigations of samples collected at high resolution from outcrops and cores covering the St. George Group carbonates suggest high degree of confidence in preservation of near-marine pristine $\delta^{13} \mathrm{C}$ signatures.

The St. George Group ${ }^{13} \mathrm{C}_{\text {carb }}$ profile exhibits negative excursions, which are correlated with variations in the sealevel fluctuations and in the $\delta^{13} \mathrm{C}_{\text {org }}$ values of the coeval kerogen. 
The sea-level reconstructions from Laurentia, Baltica, and central Australia exhibit a major sea-level lowstand around the end of Arenig, which is stratigraphically correlated with the regional St. George Unconformity. The unconformity is associated with a negative $\delta^{13} \mathrm{C}_{\text {carb }}$ excursion in the Aguathuna Formation carbonates (St. George Group) that matches a global negative $\delta^{13} \mathrm{C}_{\text {carb }}$ shift. Even if the St. George Unconformity in western Newfoundland has a significant tectonic component, it possibly also records a global sea-level lowstand.

The St. George Group $\delta^{13} \mathrm{C}_{\text {carb }}$ profile has other excursions around the mid-Tremadoc, Late Tremadoc, and middle Arenig, which can be correlated with similar shifts on the global profile. However, correlations with global excursions have to be taken with cautions, since local environmental changes (e.g., tectonism) might also result in similar excursions. Additional geochemical studies on the St. George Group carbonates from other locations in western Newfoundland will certainly provide more conclusive constraints on this issue.

\section{Acknowledgement}

The authors wish to thank Dr. Brian Pratt and an anonymous reviewer for their constructive reviews. Also, efforts of Drs. George Dix (Associate Editor) and John Greenough (Editor) are much appreciated. This project was supported by funding (to Karem Azmy) from the Earth Science Sector of Natural Resources Canada (NRCan), the Pan-Atlantic Petroleum Systems Consortium (PPSC), and the Irish Shelf Petroleum Studies Group (ISGSP).

\section{References}

Azmy, K., Veizer, J., Misi, R., De Olivia, T., Sanches, A.L., and Dardenne, M. 2001. Isotope stratigraphy of the neoproterozoic carbonate of vazante formation Saõ Francisco Basin, Brazil. Precambrian Research, 112: 303-329. doi:10.1016/S0301-9268(01) 00194-2.

Azmy, K., Kaufman, A.J., Misi, A., and Oliveira, T.F. 2006. Isotope stratigraphy of the Lapa Formation, São Francisco Basin, Brazil: Implications for Late Neoproterozoic glacial events in South America. Precambrian Research, 149(3-4): 231-248. doi:10.1016/j.precamres.2006.07.001.

Azmy, K., Lavoie, D., Knight, I., and Chi, G. 2008. Dolomitization of the Aguathuna Carbonates in Western Newfoundland, Canada: implications for a potential hydrocarbon reservoir. Canadian Journal of Earth Sciences, 45(7): 795-813. doi:10.1139/ E08-020.

Azmy, K., Lavoie, D., Knight, I., and Chi, G. 2009. Origin of Boat Harbour dolomites of the St. George Group in western Newfoundland, Canada: implications for porosity development. Bulletin of Canadian Petroleum Geology, 57: 1-24.

Baker, D., and Knight, I. 1993. The Catoche dolomite project, Anticosti Basin, eastern Canada. Centre for Earth Resources Research (CERR) Report, Memorial University of Newfoundland, St. John's, Nfld. 174 p.

Banner, J.L., and Hanson, G.N. 1990. Calculations of simultaneous isotopic and trace element variations during water-rock interaction with applications to carbonate diagenesis. Geochimica et Cosmochimica Acta, 54(11): 3123-3137. doi:10.1016/00167037(90)90128-8.

Bergström, S.M., Chen, X., Gutiérrez-Marco, J.C., and Dronov, A. 2009. The new chronostratigraphic classification of the Ordovi- cian System and its relations to major regional series and stages and to $\delta^{13} \mathrm{C}$ chemostratigraphy. Lethaia, 42(1): 97-107. doi:10. 1111/j.1502-3931.2008.00136.x.

Boyce, W.D. 1989. Early Ordovician trilobite faunas of the Boat Harbour and Catoche formations (St. George Group) in the Boat Harbour - Cape Norman area, Great Northern Peninsula, western Newfoundland. Newfoundland Department of Mines and Energy, Report 89-2, 169 p.

Boyce, W.D., and Stouge, S. 1997. Trilobite and conodont biostratigraphy of the St. George Group, Eddies Cove West area, western Newfoundland. Newfoundland Department of Mines and Energy, Report 91-1, pp. 183-200.

Boyce, W.D., Knight, I., Rohr, D.M., Williams, S.H., and Measures, E.A. 2000. The upper St. George Group, western Port au Port Peninsula: lithostratigraphy, biostratigraphy, depositional environments and regional implications. Current Research 2000. Newfoundland Department of Mines and Energy, Geological Survey Report 2000-1, pp. 101-125.

Brand, U., Logan, A., Hiller, N., and Richardson, J. 2003. Geochemistry of modern brachiopods: applications and implications for oceanography and paleoceanography. Chemical Geology, 198(3-4): 305-334. doi:10.1016/S0009-2541(03)00032-9.

Brand, U., and Veizer, J. 1980. Chemical diagenesis of a multicomponent carbonate system: 1. Trace elements. Journal of Sedimentary Petrology, 50: 1219-1236.

Buggisch, W., Keller, M., and Lehnert, O. 2003. Carbon isotope record of late Cambrian to Early Ordovician carbonates of the Argentine Precordillera. Palaeogeography, Palaeoclimatology, Palaeoecology, 195(3-4): 357-373. doi:10.1016/S0031-0182(03) 00365-1.

Cawood, P.A., McCausland, P.J.A., and Dunning, G.R. 2001. Opening Iapetus: Constraints from Laurentian margin in Newfoundland. Geological Society of America Bulletin, 113(4): 443-453. doi:10.1130/0016-7606(2001)113<0443:OICFTL > 2.0. $\mathrm{CO} ; 2$.

Calver, C.R. 2000. Isotope stratigraphy of the Ediacarian (Neoproterozoic III) of the Adelaide Rift Complex, Australia, and the overprint of water column stratification. Precambrian Research, 100(1-3): 121-150. doi:10.1016/S0301-9268(99)00072-8.

Chi, G., and Ni, P. 2007. Equations for calculation of $\mathrm{NaCl} /$ $\left(\mathrm{NaCl}+\mathrm{CaCl}_{2}\right)$ ratios and salinities from hydrohalite-melting and ice-melting temperatures in the $\mathrm{H}_{2} \mathrm{O}-\mathrm{NaCl}-\mathrm{CaCl}_{2}$ system. Acta Petrolei Sinica, 23: 33-37.

Coleman, M.L., Walsh, J.N., and Benmore, R.A. 1989. Determination of both chemical and stable isotope composition in milligram-size carbonate samples. Sedimentary Geology, 65(34): 233-238. doi:10.1016/0037-0738(89)90025-0.

Conliffe, J., Azmy, K., Knight, I., and Lavoie, D. 2009. Dolomitization in the Lower Ordovician Watts Bight Formation of the St Georges Group, western Newfoundland. Canadian Journal of Earth Sciences, 46: 247-261. doi:10.1139/E09-019.

Cooper, M., Weissenberger, J., Knight, I., Hostad, D., Gillespie, D., Williams, H., et al. 2001. Basin evolution in western Newfoundland: New insights from hydrocarbon exploration. The American Association of Petroleum Geologists Bulletin, 85: 393-418.

Corsetti, F.A., and Kaufman, A.J. 2003. Stratigraphic investigations of carbon isotope anomalies and Neoproterozoic ice ages in Death Valley, California. Geological Society of America Bulletin, 115: 916-932. doi:10.1130/B25066.1.

Derry, L.A., Kaufman, A.J., and Jacobsen, S.B. 1992. Sedimentary cycles and environmental change in the Late Proterozoic: evidence from stable and radiogenic isotopes. Geochimica et Cosmochimica Acta, 56(3): 1317-1329. doi:10.1016/0016-7037(92) 90064-P. 
Desrochers, A., Lavoie, D., Brennan-Alpert, P., and Chi, G. Regional stratigraphic, depositional and diagenetic patterns from the interior of St. Lawrence Platform: the Lower Ordovician Romaine Formation, western Anticosti Basin, Québec. In The Great American Bank. Edited by J. Derby. American Association of Petroleum Geologist, Memoir, in press.

Dickson, J.A.D., Wood, R.A., Bu Al Rougha, H., and Shebl, H. 2008. Sulphate reduction associated with hardgrounds: lithification afterburn! Sedimentary Geology, 205(1-2): 34-39. doi:10. 1016/j.sedgeo.2008.01.005.

Gradstein, F.M., Ogg, J.G., Smith, A.G., Bleeker, W., and Lourens, L.J. 2004. A new Geologic Time Scale, with special reference to Precambrian and Neogene. Episodes, 27: 83-100.

Greene, M. 2008. Multiple generations of dolomitization in the Catoche Formation, Port au Choix, Newfoundland. M.Sc. thesis, Memorial University of Newfoundland, St. John's, Nfld., 146 p.

Halverson, G.P., Hoffman, P.F., Schrag, D.P., Maloof, A.C., and Rice, A.H.N. 2005. Toward a Neoproterozoic composite carbonisotope record. Geological Society of America Bulletin, 117(9): 1181-1207. doi:10.1130/B25630.1.

Hayes, J.M., Kaplan, I.R., and Wedeking, K.W. 1983. Precambrian organic geochemistry; preservation of the record. In Earth's earliest biosphere; its origin and evolution. Edited by J. Schopf. Princeton University Press, Princeton, N.J., pp. 93-134.

Hayes, J.M., Strauss, H., and Kaufman, A.J. 1999. The abundance of ${ }^{13} \mathrm{C}$ in marine organic matter and isotopic fractionation in the global biogeochemical cycle of carbon during the past $800 \mathrm{Ma}$. Chemical Geology, 161(1-3): 103-125. doi:10.1016/S00092541(99)00083-2.

Hoffman, P.F., and Schrag, D.P. 2002. The Snowball Earth hypothesis: testing the limits of global change. Terra Nova, 14(3): 129155. doi:10.1046/j.1365-3121.2002.00408.x.

Holmden, C., Creaser, R.A., Muehlenbachs, K., Leslie, S.A., and Bergström, S.M. 1998. Isotopic evidence for geochemical decoupling between ancient epeiric seas and bordering oceans: Implications for secular curves. Geology, 26(6): 567-570. doi:10. 1130/0091-7613(1998)026<0567:IEFGDB>2.3.CO;2.

Hotinski, R.M., Bice, K.L., Kump, L.R., Najjar, R.G., and Arthur, M.A. 2001. Ocean stagnation and end-Permian anoxia. Geology, 29(1): $\quad 7-10 . \quad$ doi:10.1130/0091-7613(2001) 029<0007:OSAEPA >2.0.CO;2.

Immenhauser, I., Holmden, C., and Patterson, W.P. 2008. Interpreting the carbon-isotope record of ancient shallow epiric seas: lessons from the Recent. Geological Association of Canada, Special Paper 48, pp. 137-174.

Jacobi, R.D. 1981. Peripheral bulge - a causal mechanism for the Lower I Middle Ordovician unconformity along the western margin of the northern Appalachians. Earth and Planetary Science Letters, 56: 245-251. doi:10.1016/0012-821X(81) 90131-X.

Ji, Z., and Barnes, C.R. 1993. A major conodont extinction event during the Early Ordovician within the Midcontinent Realm. Palaeogeography, Palaeoclimatology, Palaeoecology, 104(1-4): 37-47. doi:10.1016/0031-0182(93)90118-3.

James, N.P., Stevens, R.K., Barnes, C.R., and Knight, I. 1989. Evolution of a Lower Paleozoic continental-margin carbonate platform, northern Canadian Appalachians. In Controls on Carbonate Platform and Basin Development. Edited by P.D. Crevello, J.L. Wilson, J.F. Sarg, and J.F. Read. Society of Economic Paleontologists and Mineralogists, Special Publication 44, pp. 123-146.

Kaljo, D., Martma, T., and Saadre, T. 2007. Post-Hunnebergian Ordovician carbon isotope trend in Baltoscandia, itsenvironmental implications and some similarities with that of Nevada. Palaeo- geography, Palaeoclimatology, Palaeoecology, 245(1-2): 138155. doi:10.1016/j.palaeo.2006.02.020.

Kaufman, A.J., and Knoll, A.H. 1995. Neoproterozic variations in the C-isotopic composition of seawater: stratigraphic and biogeochemical implications. Precambrian Research, 73(1-4): 2749. doi:10.1016/0301-9268(94)00070-8.

Knight, I. 1991. Geology of Cambro-Ordovician rocks in the Port Saunders (NTS 12I/11), Castors River (NTS12I/15), St. John Island (NTS 12I/14) and Torrent River (NTS 121/10) map areas. Edited by R.F. Blackwood, C.P.G. Pereira, and D.G. Walsh. Newfoundland Department of Mines and Energy, Mineral Development Division, Report 91-4, 138 p.

Knight, I., and James, N.P. 1987. The stratigraphy of the Lower Ordovician St. George Group, western Newfoundland: the interaction between eustasy and tectonics. Canadian Journal of Earth Sciences, 24: 1927-1952. doi:10.1139/e87-185.

Knight, I., James, N.P., and Lane, T.E. 1991. The Ordovician St. George Unconformity, northern Appalcachians: the relationship of plate convergence at the St. Lawrence Promontory to the Sauk/Tippecanoe sequence boundary. Geological Society of America Bulletin, 103(9): 1200-1225. doi:10.1130/00167606(1991)103<1200:TOSGUN>2.3.CO;2.

Knight, I., Azmy, K., Greene, M., and Lavoie, D. 2007. Lithostratigraphic setting of diagenetic, isotopic, and geochemistry studies of Ibexian and Whiterockian carbonates of the St. George and Table Head groups in western Newfoundland. Current Research Newfoundland and Labrador Department of Natural Resources Geological Survey. Report 07-1, pp. 55-84.

Knight, I., Azmy, K., Boyce, D., and Lavoie, D. 2008. Tremadocian carbonates of the lower St. George Group, Port au Port Peninsula, western Newfoundland: Lithostratigraphic setting of diagenetic, isotopic, and geochemistry studies. Current Research Newfoundland and Labrador Department of Natural Resources Geological Survey. Report 08-1, pp. 1-43.

Kump, L.R., and Arthur, M.A. 1999. Interpreting carbon-isotope excursions: carbonates and organic matter. Chemical Geology, 161(1-3): 181-198. doi:10.1016/S0009-2541(99)00086-8.

Lane, T.E. 1990. Dolomitization, brecciation and zinc mineralization and their paragenetic, stratigraphic and structural relationships in the upper St. George Group (Ordovician) at Daniel's Harbour, western Newfoundland: Unpublished Ph.D. thesis, Memorial University of Newfoundland, St. John's, Nfld., 496 p.

Lavoie, D. 1994. Diachronous tectonic collapse of the Ordovician continental margin, eastern Canada: comparison between the Quebec Reentrant and the St. Lawrence Promontory. Canadian Journal of Earth Sciences, 31: 1309-1319. doi:10.1139/e94-113.

Lavoie, D., Desrochers, A., Dix, G.R., Knight, I., and Salad Hersi, O. The Great American Carbonate Bank (GACB) in eastern Canada - An overview. In The Great American Bank. Edited by J. Derby. American Association of Petroleum Geologist, Memoir, in press.

Machel, H.G., and Burton, E.A. 1991. Factors governing cathodoluminescence in calcite and doloomite, and their implications for studies of carbonate diagenesis. In Luminescence microscopy and spectroscopy, qualitative and quantitative applications. (SEPM) Short Course, 25: 37-57.

Mussman, W.J., and Read, J.G. 1986. Sedimentology and development of a passive- to convert-margin unconformity: Middle Ordovician Knox Unconformity, Virginia Appalachians. Geological Society of America Bulletin, 97(3): 282-295. doi:10.1130/0016-7606(1986)97<282:SADOAP>2.0.CO;2.

Nielsen, A.T. 1992a. Ecostratigraphy and the recognition of Arenigian (Early Ordovician) sea-level changes. In Global perspectives on Ordovician geology. Edited by B.D. Webby and J.R. 
Laurie. A.A. Balkema, Rotterdam, the Netherlands, pp. 355366.

Nielsen, A.T. 1992b. International correlation of the Arenigian (Early Ordovician) based on sequence and ecostratigraphy. In Global perspectives on Ordovician geology. Edited by B.D. Webby and J.R. Laurie. A.A. Balkema, Rotterdam, the Netherlands, pp. 367-379.

Patterson, W.P., and Walter, L.M. 1994. Depletion of ${ }^{13} \mathrm{C}$ in seawater $\mathrm{SCO}_{2}$ on modern carbonate platforms: significance for the carbon isotopic record of carbonates. Geology, 22: 885-888.

Pratt, B.R., and James, N.P. 1986. The tidal flat island model for peritidal shallow-upward sequences; St. George Group, western Newfoundland. Sedimentology, 33: 313-344.

Qing, H., and Veizer, J. 1994. Oxygen and carbon isotopic composition of Ordovician brachiopods: Implications for coeval seawater. Geochimica et Cosmochimica Acta, 58(20): 4429-4442. doi:10.1016/0016-7037(94)90345-X.

Rush, P.F., and Chafetz, H.S. 1990. Fabric retentive, nonluminescent brachiopods as indicators of original $\delta^{13} \mathrm{C}$ and $\delta^{18} \mathrm{O}$ compositions: a test. Journal of Sedimentary Petrology, 60: 968981.

Salad Hersi, O., Nowlan, G.S., and Lavoie, D. 2007. A revision of the stratigraphic nomenclature of the Cambrian-Ordovician strata of the Philipsburg tectonic slice, southern Québec. Canadian Journal of Earth Sciences, 44(12): 1775-1790. doi:10. 1139/E07-041.

Schidlowski, M., Eichmann, R., and Junge, C.E. 1975. Precambrian sedimentary carbonates: carbon and oxygen isotope geochemistry and implications for the terrestrial oxygen budget. Precambrian Research, 2(1): 1-69. doi:10.1016/0301-9268(75)90018-2.

Shields, G.A., Carden, G.A.F., Veizer, J., Meidla, T., Rong, J.-Y., and Li, R.-Y. 2003. Sr, C, and O isotope geochemistry of Ordovician brachiopods: a major isotopic event around the MiddleLate Ordovician transition. Geochimica et Cosmochimica Acta, 67(11): 2005-2025. doi:10.1016/S0016-7037(02)01116-X.

Smith, M.P. 1991. Early Ordovician conodonts of East and North Greenland. Meddelelser om Grønland Geoscience. Vol. 26, 81 p. Stenzel, S.R., Knight, I., and James, N.P. 1990. Carbonate platt- form to foreland basin: revised stratigraphy of the Table Head Group (Middle Ordovician), western Newfoundland. Canadian Journal of Earth Sciences, 27(1): 14-26. doi:10.1139/e90-002.

Stouge, S., Boyce, W.D., Christiansen, J.L., Harper, D.A.T., and Knight, I. 2001. Lower-Middle Ordovician stratigraphy of North-East Greenland. Geology of Greenland Survey Bulletin, 189: $107-114$.

Stouge, S., Boyce, W.D., Christiansen, J.L., Harper, D.A.T., and Knight, I. 2002. Vendian-Lower Ordovician stratigraphy of Ella $\varnothing$ North-East Greenland: new investigation. Geology of Greenland Survey Bulletin, 191: 117-125.

Veizer, J. 1983. Chemical diagenesis of carbonates. In Theory and application of trace element technique. Edited by M.A. Arthur, T.F. Anderson, I.R. Kaplan, J. Veizer, and L.S. Land. Stable Isotopes in Sedimentary Geology. Society of Economic Paleontologists and Mineralogists (SEPM), Short course notes 10: III-1III-100.

Veizer, J., Ala, D., Azmy, K., Bruckschen, P., Bruhn, F., Buhl, D., et al. 1999. ${ }^{87} \mathrm{Sr} /{ }^{86} \mathrm{Sr}, \delta^{18} \mathrm{O}$ and $\delta^{13} \mathrm{C}$ evolution of Phanerozoic seawater. Chemical Geology, 161(1-3): 59-88. doi:10.1016/ S0009-2541(99)00081-9.

Williams, S.H., Boyce, W.D., and James, N.P. 1987. Graptolites from the Lower-Middle Ordovician St. George and Table Head groups, western Newfoundland, and their correlation with trilobite, graptolite, brachiopod and conodont zones. Canadian Journal of Earth Sciences, 24: 456-470. doi:10.1139/e87-047.

Wilson, J.L., Medlock, P.L., Fritz, R.D., Canter, K.L., and Geesaman, R.G. 1992. A review of Cambro-Ordovician breccias in North America. In Paleokarst, karst-related diagenesis and reservoir development. Edited by M.P. Candelaria and C.L. Reed. SEPM-Permian Basin Section, Publication 92-33, pp. 19-29.

Zhang, S., and Barnes, C.R. 2004. Arenigian (Early Ordovician) sea-level history and the response of conodont communities, western Newfoundland. Canadian Journal of Earth Sciences, 41(7): 843-865. doi:10.1139/e04-036.

Zhang, R., Follows, M.J., Grotzinger, J.P., and Marshall, J. 2001. Could the Late Permian deep ocean have been anoxic? Paleoceanagraphy, 16(3): 317-329. doi:10.1029/2000PA000522. 


\section{Appendix A}

Table A1 appears on the following pages. 
Table A1. Samples, description, and elemental and stable isotopic geochemical compositions of the investigated carbonates.

\begin{tabular}{|c|c|c|c|c|c|}
\hline Sample No. & Formation & Outcrop/Core & Sample level (m) & Phase & $\mathrm{CaCO}_{3} \%$ \\
\hline R1-004 & Table Point (top) & Core RND1 & 4 & $\mathrm{C} 1$ & \\
\hline R1-010 & Table Point & Core RND1 & 10 & $\mathrm{C} 1$ & 94.5 \\
\hline R1-016 & Table Point & Core RND1 & 16 & $\mathrm{C} 1$ & 92.1 \\
\hline R1-022 & Table Point & Core RND1 & 22 & $\mathrm{C} 1$ & 94.6 \\
\hline R1-028 & Table Point & Core RND1 & 28 & $\mathrm{C} 1$ & 96.2 \\
\hline R1-034 & Table Point & Core RND1 & 34 & $\mathrm{C} 1$ & 95.6 \\
\hline R1-041 & Table Point & Core RND1 & 41 & $\mathrm{C} 1$ & 93.5 \\
\hline R1-047 & Table Point & Core RND1 & 47 & $\mathrm{C} 1$ & 69.8 \\
\hline R1-053 & Table Point & Core RND1 & 53 & $\mathrm{C} 1$ & 93.9 \\
\hline R1-059 & Table Point & Core RND1 & 59 & $\mathrm{C} 1$ & \\
\hline R1-065 & Table Point & Core RND1 & 65 & $\mathrm{C} 1$ & 96.8 \\
\hline R1-071 & Table Point & Core RND1 & 71 & $\mathrm{C} 1$ & 92.3 \\
\hline R1-075 & Table Point & Core RND1 & 75 & $\mathrm{C} 1$ & 97.1 \\
\hline R1-079 & Table Point (base) & Core RND1 & 79 & $\mathrm{C} 1$ & \\
\hline KAR1-081 & Aguathuna (top) & Core RND1 & 81 & D1 & 55.7 \\
\hline KAR1-083 & Aguathuna & Core RND1 & 83 & D1 & \\
\hline KAR1-085 & Aguathuna & Core RND1 & 85 & D1 & 55.4 \\
\hline KAR1-087 & Aguathuna & Core RND1 & 87 & D1 & \\
\hline KAR1-089 & Aguathuna & Core RND1 & 89 & D1 & 55.0 \\
\hline KAR1-091 & Aguathuna & Core RND1 & 91 & D1 & \\
\hline KAR1-093 & Aguathuna & Core RND1 & 93 & D1 & 54.8 \\
\hline KAR1-095 & Aguathuna & Core RND1 & 95 & D1 & \\
\hline KAR1-099 & Aguathuna & Core RND1 & 99 & D1 & 56.1 \\
\hline KAR1-102 & Aguathuna & Core RND1 & 102 & D1 & 53.0 \\
\hline KAR1-106 & Aguathuna & Core RND1 & 106 & D1 & 55.8 \\
\hline KAR1-108 & Aguathuna & Core RND1 & 108 & D1 & \\
\hline KAR1-110 & Aguathuna & Core RND1 & 110 & $\mathrm{C} 1$ & 99.2 \\
\hline KAR1-112 & Aguathuna & Core RND1 & 112 & $\mathrm{C} 1$ & 95.0 \\
\hline KAR1-118 & Aguathuna & Core RND1 & 118 & D1 & \\
\hline KAR1-120 & Aguathuna & Core RND1 & 120 & D1 & 56.5 \\
\hline KAR1-122 & Aguathuna & Core RND1 & 122 & D1 & 55.5 \\
\hline KAR1-124 & Aguathuna & Core RND1 & 124 & $\mathrm{C} 1$ & 99.4 \\
\hline KAR1-128 & Aguathuna & Core RND1 & 128 & D1 & \\
\hline KAR1-130 & Aguathuna & Core RND1 & 130 & D1 & 55.1 \\
\hline KAR1-132 & Aguathuna & Core RND1 & 132 & D1 & \\
\hline KAR1-134 & Aguathuna & Core RND1 & 134 & D1 & \\
\hline KAR1-136 & Aguathuna & Core RND1 & 136 & $\mathrm{C} 1$ & 99.3 \\
\hline KAR1-138 & Aguathuna & Core RND1 & 138 & D1 & \\
\hline KAR1-142 & Aguathuna & Core RND1 & 142 & D1 & 54.7 \\
\hline KAR1-144 & Aguathuna & Core RND1 & 144 & D1 & 54.9 \\
\hline KAR1-146 & Aguathuna & Core RND1 & 146 & D1 & \\
\hline KAR1-148 & Aguathuna & Core RND1 & 148 & D1 & \\
\hline KAR1-150 & Aguathuna & Core RND1 & 150 & D1 & 58.3 \\
\hline KAR1-154 & Aguathuna & Core RND1 & 154 & $\mathrm{C} 1$ & \\
\hline KAR1-160 & Aguathuna & Core RND1 & 160 & $\mathrm{C} 1$ & 97.4 \\
\hline KAR1-162 & Aguathuna & Core RND1 & 162 & D1 & 55.3 \\
\hline KAR1-164 & Aguathuna & Core RND1 & 164 & D1 & 55.1 \\
\hline KAR1-166 & Aguathuna & Core RND1 & 166 & $\mathrm{C} 1$ & 99.2 \\
\hline KAR1-168 & Aguathuna & Core RND1 & 168 & $\mathrm{C} 1$ & 99.4 \\
\hline KAR1-172 & Aguathuna & Core RND1 & 172 & $\mathrm{C} 1$ & 98.3 \\
\hline KAR1-174 & Aguathuna & Core RND1 & 174 & $\mathrm{C} 1$ & \\
\hline KAR1-176 & Aguathuna (base) & Core RND1 & 176 & $\mathrm{C} 1$ & \\
\hline 49 & Catoche-Costa Bay Mbr. Dolomite (top) & Core PC79-02 & 44.1 & D1 & 55.6 \\
\hline 44 & Catoche-Costa Bay Mbr. Dolomite & Core PC79-02 & 37.5 & D1 & 61.0 \\
\hline 40 & Catoche-Costa Bay Mbr. Dolomite & Core PC79-02 & 33.5 & D1 & 55.0 \\
\hline 37 & Catoche-Costa Bay Mbr. Dolomite & Core PC79-02 & 30.5 & D1 & \\
\hline 31 & Catoche-Costa Bay Mbr. Dolomite & Core PC79-02 & 24.5 & D1 & 54.6 \\
\hline
\end{tabular}




\begin{tabular}{|c|c|c|c|c|c|c|c|c|}
\hline $\mathrm{MgCO}_{3} \%$ & $\begin{array}{l}\mathrm{Mn} \\
(\mathrm{ppm})\end{array}$ & $\begin{array}{l}\mathrm{Sr} \\
(\mathrm{ppm})\end{array}$ & $\begin{array}{l}\delta^{18} \mathrm{O} \% \\
\mathrm{VPDB}\end{array}$ & $\begin{array}{l}\delta^{13} \mathrm{C} \text { carbonate } \\
\% \text { VPDB }\end{array}$ & $\begin{array}{l}\delta^{13} \mathrm{C} \text { organic } \\
\% \text { VPDB }\end{array}$ & TOC \% & $\Delta \delta$ & Carbonate $\%$ \\
\hline & & & -6.2 & -2.0 & -31.1 & 0.05 & 29.0 & 90.9 \\
\hline 5.5 & 559 & 340 & -6.3 & -1.5 & -31.0 & 0.07 & 29.5 & 91.8 \\
\hline 7.9 & 712 & 325 & -5.4 & -1.2 & -30.3 & 0.05 & 29.1 & 91.3 \\
\hline 5.4 & 336 & 379 & -6.6 & -1.1 & -30.7 & 0.02 & 29.6 & 98.0 \\
\hline 3.8 & 164 & 367 & -6.1 & -1.1 & -30.1 & 0.03 & 29.0 & 97.5 \\
\hline 4.4 & 150 & 396 & -6.5 & -1.7 & -30.8 & 0.09 & 29.1 & 91.0 \\
\hline 6.5 & 230 & 393 & -6.0 & -1.3 & & & & \\
\hline 30.2 & 135 & 286 & -5.0 & -1.3 & -31.1 & 0.12 & 29.8 & 86.2 \\
\hline \multirow[t]{2}{*}{6.1} & 66 & 380 & -6.3 & -1.2 & -30.9 & 0.09 & 29.7 & 92.6 \\
\hline & & & -6.1 & -1.1 & -30.6 & 0.07 & 29.5 & 97.4 \\
\hline 3.2 & 58 & 231 & -6.1 & -0.8 & & & & \\
\hline 7.7 & 108 & 269 & -6.1 & -1.3 & -29.2 & 0.02 & 27.8 & 95.9 \\
\hline \multirow[t]{2}{*}{2.9} & 160 & 329 & -6.6 & -1.8 & -32.0 & 0.07 & 30.3 & 99.3 \\
\hline & & & -7.0 & -0.7 & -27.5 & 0.01 & 26.9 & 97.5 \\
\hline \multirow[t]{2}{*}{44.3} & 239 & 90 & -3.2 & -2.6 & -26.9 & 0.01 & 24.4 & 95.2 \\
\hline & & & -3.5 & -2.4 & & & & \\
\hline \multirow[t]{2}{*}{44.6} & 177 & 91 & -3.7 & -2.2 & -26.5 & 0.01 & 24.2 & 93.4 \\
\hline & & & -3.9 & -1.6 & -27.4 & 0.01 & 25.9 & 96.6 \\
\hline \multirow[t]{2}{*}{45.0} & 149 & 87 & -4.2 & -1.9 & & & & \\
\hline & & & -2.9 & -1.1 & -26.4 & 0.01 & 25.3 & 97.8 \\
\hline \multirow{2}{*}{45.2} & 70 & 92 & -3.8 & -1.4 & -27.0 & 0.01 & 25.5 & 98.6 \\
\hline & & & -4.2 & -2.1 & -28.1 & 0.02 & 26.1 & 84.7 \\
\hline 43.9 & 585 & 96 & -4.4 & -3.1 & -29.2 & 0.02 & 26.0 & 94.0 \\
\hline 47.0 & 741 & 96 & -4.7 & -1.8 & & & & \\
\hline \multirow[t]{2}{*}{44.2} & 120 & 104 & -4.1 & -1.6 & -27.6 & 0.01 & 25.9 & 90.3 \\
\hline & & & -4.5 & -1.9 & & & & \\
\hline 0.8 & 58 & 204 & -7.0 & -2.8 & -29.5 & 0.04 & 26.8 & 92.7 \\
\hline \multirow[t]{2}{*}{5.0} & 109 & 653 & -7.1 & -1.8 & & & & \\
\hline & & & -5.4 & -1.3 & -28.1 & 0.02 & 26.7 & 97.4 \\
\hline 43.5 & 346 & 79 & -4.6 & -1.5 & & & & \\
\hline 44.5 & 320 & 76 & -3.8 & -1.5 & & & & \\
\hline \multirow[t]{2}{*}{0.6} & 45 & 182 & -6.9 & -1.8 & -29.1 & 0.02 & 27.3 & 98.4 \\
\hline & & & -5.1 & -1.8 & & & & \\
\hline \multirow[t]{3}{*}{44.9} & 348 & 66 & -3.7 & -1.4 & & & & \\
\hline & & & -3.8 & -1.3 & -27.0 & 0.02 & 25.7 & 93.0 \\
\hline & & & -3.0 & -1.9 & -27.8 & 0.06 & 25.9 & 90.4 \\
\hline \multirow[t]{2}{*}{0.7} & 48 & 355 & -7.2 & -1.8 & & & & \\
\hline & & & -3.3 & -1.2 & -28.8 & 0.07 & 27.6 & 92.5 \\
\hline 45.3 & 237 & 72 & -3.7 & -1.6 & -27.1 & 0.02 & 25.6 & 96.4 \\
\hline \multirow[t]{3}{*}{45.1} & 126 & 109 & -4.3 & -1.5 & & & & \\
\hline & & & -4.4 & -1.3 & -27.2 & 0.04 & 25.9 & 79.2 \\
\hline & & & -3.6 & -1.2 & & & & \\
\hline \multirow[t]{2}{*}{41.7} & 836 & 129 & -4.3 & -1.1 & -27.9 & 0.02 & 26.9 & 84.9 \\
\hline & & & -6.6 & -0.4 & -28.4 & 0.00 & 28.0 & 99.7 \\
\hline 2.6 & 229 & 232 & -7.5 & -1.8 & -29.7 & 0.07 & 27.9 & 98.3 \\
\hline 44.7 & 219 & 73 & -4.8 & -0.7 & & & & \\
\hline 44.9 & 202 & 117 & -3.9 & -0.6 & -27.2 & 0.69 & 26.5 & 94.7 \\
\hline 0.8 & 26 & 312 & -8.0 & -1.0 & & & & \\
\hline 0.6 & 69 & 254 & -7.6 & -0.7 & -27.8 & 0.02 & 27.1 & 99.5 \\
\hline \multirow[t]{3}{*}{1.7} & 39 & 208 & -7.2 & -1.0 & -25.7 & 0.03 & 24.7 & 75.8 \\
\hline & & & -7.7 & -0.4 & & & & \\
\hline & & & -5.9 & -0.6 & & & & \\
\hline 44.4 & 122 & 63 & -7.0 & -0.9 & -29.1 & 0.16 & 28.2 & 83.4 \\
\hline 39.0 & 159 & 37 & -7.2 & -0.6 & & & & \\
\hline \multirow[t]{2}{*}{45.0} & 116 & 51 & -7.7 & -0.4 & & & & \\
\hline & & & -8.3 & -0.7 & & & & \\
\hline 45.4 & 124 & 33 & -9.8 & -0.2 & & & & \\
\hline
\end{tabular}


Table A1 (continued).

\begin{tabular}{|c|c|c|c|c|c|}
\hline Sample No. & Formation & Outcrop/Core & Sample level (m) & Phase & $\mathrm{CaCO}_{3} \%$ \\
\hline 27 & Catoche-Costa Bay Mbr. Dolomite & Core PC79-02 & 18.5 & D1 & 60.8 \\
\hline 22 & Catoche-Costa Bay Mbr. Dolomite & Core PC79-02 & 13.5 & D1 & \\
\hline 20 & Catoche-Costa Bay Mbr. Dolomite & Core PC79-02 & 11.5 & D1 & \\
\hline 17 & Catoche-Costa Bay Mbr. Dolomite & Core PC79-02 & 6.5 & D1 & \\
\hline 15 & Catoche-Costa Bay Mbr. Dolomite & Core PC79-02 & 6.5 & D1 & \\
\hline 13 & Catoche-Costa Bay Mbr. Dolomite & Core PC79-02 & 4.5 & D1 & \\
\hline 11 & Catoche-Costa Bay Mbr. Dolomite & Core PC79-02 & 2.5 & D1 & 61.1 \\
\hline 10 & Catoche-Costa Bay Mbr. Dolomite & Core PC79-02 & 1.5 & D1 & \\
\hline 9 & Catoche-Costa Bay Mbr. Dolomite (base) & Core PC79-02 & 0.4 & D1 & 52.9 \\
\hline 131 & Catoche (top) & Outcrop & 120 & D1 & \\
\hline 130 & Catoche & Outcrop & 119 & $\mathrm{C} 1$ & 98.6 \\
\hline 129 & Catoche & Outcrop & 111 & $\mathrm{C} 1$ & 93.6 \\
\hline 128 & Catoche & Outcrop & 107 & $\mathrm{C} 1$ & \\
\hline 127 & Catoche & Outcrop & 102 & $\mathrm{C} 1$ & \\
\hline 126 & Catoche & Outcrop & 98 & D1 & 65.8 \\
\hline 125 & Catoche & Outcrop & 95 & $\mathrm{C} 1$ & 94.9 \\
\hline 124 & Catoche & Outcrop & 92 & $\mathrm{C} 1$ & \\
\hline 123 & Catoche & Outcrop & 89 & $\mathrm{C} 1$ & 98.9 \\
\hline 120 & Catoche & Outcrop & 82 & $\mathrm{C} 1$ & \\
\hline 119 & Catoche & Outcrop & 77 & $\mathrm{C} 1$ & \\
\hline 118 & Catoche & Outcrop & 71 & $\mathrm{C} 1$ & \\
\hline 117 & Catoche & Outcrop & 67 & $\mathrm{C} 1$ & 98.5 \\
\hline 116 & Catoche & Outcrop & 62 & $\mathrm{C} 1$ & \\
\hline 115 & Catoche & Outcrop & 57 & $\mathrm{C} 1$ & 97.8 \\
\hline 114 & Catoche & Outcrop & 55 & $\mathrm{C} 1$ & \\
\hline 113 & Catoche & Outcrop & 50 & $\mathrm{C} 1$ & 98.5 \\
\hline 111 & Catoche & Outcrop & 43 & D1 & \\
\hline 110 & Catoche & Outcrop & 41 & $\mathrm{C} 1$ & 97.1 \\
\hline 109 & Catoche & Outcrop & 35 & $\mathrm{C} 1$ & \\
\hline 108 & Catoche & Outcrop & 30 & $\mathrm{C} 1$ & 98.5 \\
\hline 107 & Catoche & Outcrop & 25 & $\mathrm{C} 1$ & \\
\hline 106 & Catoche & Outcrop & 12 & $\mathrm{C} 1$ & 98.7 \\
\hline 105 & Catoche & Outcrop & 8 & $\mathrm{C} 1$ & \\
\hline 104 & Catoche & Outcrop & 5 & $\mathrm{C} 1$ & \\
\hline 103 & Catoche & Outcrop & 4 & $\mathrm{C} 1$ & 98.7 \\
\hline 102 & Catoche & Outcrop & 4 & $\mathrm{C} 1$ & \\
\hline 100 & Catoche (base) & Outcrop & 1 & $\mathrm{C} 1$ & \\
\hline BH67 (top) & Boat Harbour & Outcrop & 174 & $\mathrm{C} 1$ & 97.1 \\
\hline BH66 & Boat Harbour & Outcrop & 172 & $\mathrm{C} 1$ & 99.4 \\
\hline BH64 & Boat Harbour & Outcrop & 168 & $\mathrm{C} 1$ & \\
\hline BH62 & Boat Harbour & Outcrop & 165 & $\mathrm{C} 1$ & 98.8 \\
\hline BH60 & Boat Harbour & Outcrop & 161 & D1 & \\
\hline BH58 & Boat Harbour & Outcrop & 158 & D1 & 77.5 \\
\hline BH56 & Boat Harbour & Outcrop & 154 & $\mathrm{C} 1$ & \\
\hline BH55 & Boat Harbour & Outcrop & 152 & $\mathrm{C} 1$ & \\
\hline BH53 & Boat Harbour & Outcrop & 148 & D1 & \\
\hline BH51 & Boat Harbour & Outcrop & 144.5 & $\mathrm{C} 1$ & \\
\hline BH50 & Boat Harbour & Outcrop & 142 & D1 & \\
\hline BH49 & Boat Harbour & Outcrop & 141 & $\mathrm{C} 1$ & \\
\hline BH47 & Boat Harbour & Outcrop & 138 & $\mathrm{C} 1$ & \\
\hline BH45 & Boat Harbour & Outcrop & 135 & D1 & 72.4 \\
\hline BH43 & Boat Harbour & Outcrop & 130 & $\mathrm{C} 1$ & 99.0 \\
\hline BH41 & Boat Harbour & Outcrop & 126 & D1 & \\
\hline $\mathrm{BH} 40$ & Boat Harbour & Outcrop & 125 & D1-C1 & 79.3 \\
\hline BH38b & Boat Harbour & Outcrop & 122 & D1 & 71.5 \\
\hline BH37 & Boat Harbour & Outcrop & 120 & $\mathrm{C} 1$ & 99.2 \\
\hline
\end{tabular}




\begin{tabular}{|c|c|c|c|c|c|c|c|c|}
\hline $\mathrm{MgCO}_{3} \%$ & $\begin{array}{l}\mathrm{Mn} \\
(\mathrm{ppm})\end{array}$ & $\begin{array}{l}\mathrm{Sr} \\
(\mathrm{ppm})\end{array}$ & $\begin{array}{l}\delta^{18} \mathrm{O} \% \\
\mathrm{VPDB}\end{array}$ & $\begin{array}{l}\delta^{13} \mathrm{C} \text { carbonate } \\
\% \text { VPDB }\end{array}$ & $\begin{array}{l}\delta^{13} \mathrm{C} \text { organic } \\
\% \text { VPDB }\end{array}$ & TOC $\%$ & $\Delta \delta$ & Carbonate $\%$ \\
\hline \multirow[t]{6}{*}{39.2} & 155 & 33 & -9.1 & -0.4 & & & & \\
\hline & & & -8.5 & -0.7 & -27.7 & 0.03 & 27.0 & 99.1 \\
\hline & & & -8.5 & 0.0 & -35.0 & 0.02 & 35.0 & 99.4 \\
\hline & & & -8.5 & -0.7 & -27.5 & 0.00 & 26.8 & \\
\hline & & & -8.5 & 0.0 & -28.2 & 0.00 & 28.3 & 99.7 \\
\hline & & & -9.9 & -0.5 & & & & \\
\hline \multirow[t]{2}{*}{38.9} & 100 & 33 & -9.3 & -0.6 & -29.2 & 0.01 & 28.6 & \\
\hline & & & -11.2 & -0.8 & & & & 98.7 \\
\hline \multirow{2}{*}{47.1} & 97 & 66 & -6.7 & -0.6 & & & & \\
\hline & & & -8.6 & -1.7 & -29.4 & 0.07 & 27.7 & 93.4 \\
\hline 1.4 & 68 & 291 & -8.7 & -1.4 & -29.5 & 0.03 & 28.2 & 97.9 \\
\hline \multirow{3}{*}{6.4} & 70 & 293 & -9.0 & -1.5 & & & & \\
\hline & & & -8.9 & -1.7 & & & & \\
\hline & & & -8.3 & -1.7 & -27.4 & 0.03 & 25.7 & 97.4 \\
\hline 34.2 & 178 & 66 & -9.2 & -1.5 & & & & \\
\hline \multirow[t]{2}{*}{5.1} & 40 & 363 & -8.8 & -2.0 & -29.9 & 0.05 & 27.8 & 94.9 \\
\hline & & & -8.1 & -2.1 & -28.6 & 0.04 & 26.5 & 93.0 \\
\hline \multirow[t]{4}{*}{1.1} & 33 & 391 & -8.0 & -2.0 & -27.5 & 0.07 & 25.5 & 91.6 \\
\hline & & & -8.2 & -2.4 & & & & \\
\hline & & & -8.2 & -2.6 & -27.8 & 0.93 & 25.2 & 94.1 \\
\hline & & & -7.9 & -2.3 & & & & \\
\hline \multirow[t]{2}{*}{1.5} & 31 & 405 & -7.9 & -3.2 & -28.4 & 0.07 & 25.2 & 95.6 \\
\hline & & & -8.6 & -2.8 & & & & \\
\hline \multirow{2}{*}{2.2} & 47 & 336 & -8.5 & -2.7 & -27.8 & 0.04 & 25.1 & 97.0 \\
\hline & & & -8.9 & -2.2 & & & & \\
\hline \multirow[t]{2}{*}{1.5} & 33 & 291 & -8.2 & -1.9 & -27.3 & 0.19 & 25.5 & 82.6 \\
\hline & & & -8.3 & -2.1 & & & & \\
\hline \multirow[t]{2}{*}{2.9} & 50 & 420 & -7.7 & -0.8 & -29.1 & 0.04 & 28.2 & 91.1 \\
\hline & & & -7.5 & -2.2 & & & & \\
\hline \multirow[t]{2}{*}{1.5} & 71 & 326 & -8.0 & -2.3 & & & & \\
\hline & & & -9.0 & -1.6 & -26.8 & 0.02 & 25.1 & 98.3 \\
\hline \multirow[t]{3}{*}{1.3} & 82 & 352 & -7.9 & -2.0 & -28.8 & 0.04 & 26.8 & 90.1 \\
\hline & & & -7.8 & -2.6 & -26.4 & 0.22 & 23.8 & 76.4 \\
\hline & & & -8.5 & -2.4 & & & & \\
\hline \multirow[t]{3}{*}{1.3} & 47 & 326 & -8.3 & -2.3 & -28.6 & 0.01 & 26.3 & 98.3 \\
\hline & & & -8.7 & -3.0 & & & & \\
\hline & & & -9.3 & -1.9 & & & & \\
\hline 2.9 & 148 & 479 & -7.1 & -1.8 & -25.1 & 0.26 & & 91.3 \\
\hline \multirow[t]{2}{*}{0.6} & 65 & 250 & -7.3 & -2.5 & -22.2 & 0.64 & 19.7 & 96.3 \\
\hline & & & -7.0 & -2.0 & & & & \\
\hline \multirow[t]{2}{*}{1.2} & 87 & 384 & -7.2 & -2.8 & -29.4 & 0.22 & 26.6 & 93.0 \\
\hline & & & -6.3 & -2.4 & & & & \\
\hline \multirow[t]{8}{*}{22.5} & 715 & 193 & -6.6 & -2.0 & -25.4 & 0.38 & 23.5 & 85.5 \\
\hline & & & -6.0 & -3.0 & -26.6 & 1.50 & & \\
\hline & & & -7.1 & -4.2 & -26.7 & 1.88 & 22.4 & 98.5 \\
\hline & & & -5.9 & -3.2 & -26.4 & 2.05 & 23.1 & 98.8 \\
\hline & & & -7.7 & -3.0 & & & & \\
\hline & & & -5.2 & -3.2 & -25.4 & 0.45 & 22.2 & 96.8 \\
\hline & & & -7.0 & -3.2 & & & & \\
\hline & & & -8.5 & -2.8 & & & & \\
\hline 27.6 & 306 & 110 & -4.0 & -2.7 & -26.1 & 0.12 & 23.4 & 93.2 \\
\hline 1.0 & 38 & 419 & -7.3 & -2.9 & & & & \\
\hline & & & -6.7 & -3.3 & -26.6 & 0.22 & 23.3 & 93.7 \\
\hline 20.7 & 391 & 98 & -7.7 & -2.5 & & & & \\
\hline 28.5 & 182 & 128 & -6.5 & -2.4 & -28.2 & 0.90 & 25.9 & 97.9 \\
\hline 0.8 & 62 & 380 & -7.6 & -3.0 & -27.4 & 1.19 & 24.4 & 98.0 \\
\hline
\end{tabular}


Table A1 (continued).

\begin{tabular}{|c|c|c|c|c|c|}
\hline Sample No. & Formation & Outcrop/Core & Sample level (m) & Phase & $\mathrm{CaCO}_{3} \%$ \\
\hline BH36 & Boat Harbour & Outcrop & 118 & D1 & \\
\hline ВH35 & Boat Harbour & Outcrop & 116 & D1 & \\
\hline BH34 & Boat Harbour & Outcrop & 114 & D1 & \\
\hline BH33 & Boat Harbour & Outcrop & 112.5 & $\mathrm{D} 1$ & \\
\hline BH32 & Boat Harbour & Outcrop & 110 & D1 & 76.4 \\
\hline ВH30 & Boat Harbour & Outcrop & 106 & D1 & 75.0 \\
\hline BH 28 & Boat Harbour & Outcrop & 102 & $\mathrm{C} 1$ & \\
\hline BH26 & Boat Harbour & Outcrop & 98 & D1 & \\
\hline $\mathrm{BH} 24$ & Boat Harbour & Outcrop & 94 & D1 & 74.3 \\
\hline $\mathrm{BH} 22$ & Boat Harbour & Outcrop & 89.5 & $\mathrm{C} 1$ & 98.7 \\
\hline $\mathrm{BH} 20$ & Boat Harbour & Outcrop & 85.5 & D1 & 74.4 \\
\hline BH18 & Boat Harbour & Outcrop & 82 & D1 & 69.5 \\
\hline BH16 & Boat Harbour & Outcrop & 78 & $\mathrm{C} 1$ & 98.8 \\
\hline BH14 & Boat Harbour & Outcrop & 74 & D1 & 72.6 \\
\hline BH12 & Boat Harbour & Outcrop & 68.5 & D1 & \\
\hline $\mathrm{BH} 10$ & Boat Harbour & Outcrop & 64.5 & $\mathrm{C} 1$ & \\
\hline BH08 & Boat Harbour & Outcrop & 61 & D1 & 72.2 \\
\hline BH06 & Boat Harbour & Outcrop & 56 & $\mathrm{C} 1$ & \\
\hline BH04 & Boat Harbour & Outcrop & 52 & $\mathrm{C} 1$ & \\
\hline ВH02 & Boat Harbour & Outcrop & 48 & $\mathrm{C} 1$ & 99.2 \\
\hline BH-A23 & Boat Harbour & Outcrop & 44 & $\mathrm{C} 1$ & \\
\hline BH-A17 & Boat Harbour & Outcrop & 30 & D1 & 76.9 \\
\hline BH-A 15 & Boat Harbour & Outcrop & 25.5 & D1 & 72.4 \\
\hline BH-A14 & Boat Harbour & Outcrop & 24 & $\mathrm{C} 1$ & \\
\hline BH-A11 & Boat Harbour & Outcrop & 19 & D1 & \\
\hline BH-A09 & Boat Harbour & Outcrop & 15 & D1 & \\
\hline BH-A07-2 & Boat Harbour & Outcrop & 11 & D1 & 69.4 \\
\hline BH-A05 & Boat Harbour & Outcrop & 8 & $\mathrm{C} 1$ & 75.6 \\
\hline BH-A03 & Boat Harbour & Outcrop & 3 & D1 & 68.5 \\
\hline BH-A02 & Boat Harbour & Outcrop & 2 & $\mathrm{C} 1$ & 99.1 \\
\hline BH-A01 (base) & Boat Harbour & Outcrop & 0.5 & $\mathrm{C} 1$ & 99.2 \\
\hline WB30 (top) & Watts Bight & Outcrop & 68 & $\mathrm{C} 1$ & 98.5 \\
\hline WB29 & Watts Bight & Outcrop & 66 & & \\
\hline WB28 & Watts Bight & Outcrop & 63 & & \\
\hline WB27 & Watts Bight & Outcrop & 61.5 & & \\
\hline WB26 & Watts Bight & Outcrop & 60 & $\mathrm{C} 1$ & 99.1 \\
\hline WB25 & Watts Bight & Outcrop & 59 & D1 & 64.3 \\
\hline WB24 & Watts Bight & Outcrop & 57 & & \\
\hline WB23 & Watts Bight & Outcrop & 55 & & \\
\hline WB22 & Watts Bight & Outcrop & 58 & D1 & 54.2 \\
\hline WB21 & Watts Bight & Outcrop & 57 & & \\
\hline WB20 & Watts Bight & Outcrop & 54 & & \\
\hline WB19 & Watts Bight & Outcrop & 52 & & \\
\hline WB18 & Watts Bight & Outcrop & 50.5 & D1 & 54.8 \\
\hline WB17 & Watts Bight & Outcrop & 48 & & \\
\hline WB16 & Watts Bight & Outcrop & 46 & D1 & \\
\hline WB15A & Watts Bight & Outcrop & 43.5 & D1 & 97.0 \\
\hline WB14 & Watts Bight & Outcrop & 42 & D1 & \\
\hline WB13 & Watts Bight & Outcrop & 40 & D1 & \\
\hline WB12 & Watts Bight & Outcrop & 38 & $\mathrm{C} 1$ & \\
\hline WB11 & Watts Bight & Outcrop & 36 & & \\
\hline WB10 & Watts Bight & Outcrop & 34 & D1 & 64.1 \\
\hline WB09 & Watts Bight & Outcrop & 32 & & \\
\hline WB08 & Watts Bight & Outcrop & 30 & $\mathrm{C} 1$ & 98.4 \\
\hline WB07 & Watts Bight & Outcrop & 27.5 & D1 & \\
\hline WB06 & Watts Bight & Outcrop & 25 & $\mathrm{C} 1$ & \\
\hline
\end{tabular}




\begin{tabular}{|c|c|c|c|c|c|c|c|c|}
\hline $\mathrm{MgCO}_{3} \%$ & $\begin{array}{l}\mathrm{Mn} \\
(\mathrm{ppm})\end{array}$ & $\begin{array}{l}\mathrm{Sr} \\
(\mathrm{ppm})\end{array}$ & $\begin{array}{l}\delta^{18} \mathrm{O} \% \text { o } \\
\mathrm{VPDB}\end{array}$ & $\begin{array}{l}\delta^{13} \mathrm{C} \text { carbonate } \\
\% \text { VPDB }\end{array}$ & $\begin{array}{l}\delta^{13} \mathrm{C} \text { organic } \\
\% \text { VPDB }\end{array}$ & TOC $\%$ & $\Delta \delta$ & Carbonate $\%$ \\
\hline & & & -6.8 & -2.4 & & & & \\
\hline & & & -6.9 & -2.5 & -35.1 & 0.57 & 32.6 & 94.3 \\
\hline & & & -7.3 & -2.4 & & & & \\
\hline & & & -5.6 & -2.1 & & & & \\
\hline 23.6 & 244 & 198 & -6.1 & -1.9 & -25.4 & 0.40 & 23.5 & 95.0 \\
\hline \multirow[t]{3}{*}{25.0} & 270 & 187 & -6.1 & -2.3 & & & & \\
\hline & & & -7.6 & -3.0 & -28.6 & 0.58 & 25.6 & 94.4 \\
\hline & & & -5.8 & -1.8 & -24.4 & 2.66 & 22.7 & 96.6 \\
\hline 25.7 & 251 & 166 & -6.1 & -2.4 & & & & \\
\hline 1.3 & 47 & 357 & -7.6 & -2.8 & -28.8 & 0.69 & 26.0 & 93.8 \\
\hline 25.6 & 124 & 244 & -5.6 & -1.9 & -25.5 & 0.16 & 23.7 & 90.6 \\
\hline 30.5 & 141 & 126 & -5.4 & -2.0 & & & & \\
\hline 1.2 & 57 & 360 & -7.5 & -2.5 & & & & \\
\hline \multirow[t]{3}{*}{27.4} & 240 & 209 & -5.6 & -2.1 & -26.9 & 0.18 & 24.8 & 85.4 \\
\hline & & & -7.1 & -2.3 & & & & \\
\hline & & & -7.8 & -2.3 & & & & \\
\hline \multirow[t]{3}{*}{27.8} & 553 & 138 & -6.5 & -0.9 & -25.6 & 0.16 & 24.6 & 90.3 \\
\hline & & & -8.0 & -2.2 & & & & \\
\hline & & & -7.0 & -1.9 & -24.4 & 0.23 & 22.5 & 90.0 \\
\hline \multirow[t]{2}{*}{0.8} & 62 & 242 & -8.1 & -2.6 & -25.6 & 0.14 & 23.0 & 90.2 \\
\hline & & & -7.7 & -3.6 & -24.5 & 0.34 & 20.9 & 96.4 \\
\hline 23.1 & 239 & 204 & -6.6 & -1.7 & & & & \\
\hline \multirow[t]{4}{*}{27.6} & 304 & 175 & -6.5 & -1.1 & -24.8 & 0.20 & 23.7 & 90.2 \\
\hline & & & -6.8 & -1.8 & -22.1 & 0.09 & 20.3 & 75.2 \\
\hline & & & -6.6 & -1.5 & & & & \\
\hline & & & -6.3 & -1.8 & -27.5 & 0.33 & 25.7 & 93.2 \\
\hline 30.6 & 163 & 132 & -7.3 & -0.9 & -25.6 & 0.38 & 24.7 & 96.0 \\
\hline 24.4 & 276 & 236 & -5.7 & -1.7 & & & & \\
\hline 31.5 & 218 & 143 & -5.7 & -1.4 & -25.8 & 0.51 & 24.4 & 90.9 \\
\hline 0.9 & 78 & 304 & -8.1 & -2.3 & -25.2 & 0.20 & 22.9 & 82.3 \\
\hline 0.8 & 57 & 268 & -8.5 & -2.0 & -25.7 & 0.18 & 23.7 & 92.1 \\
\hline \multirow[t]{2}{*}{1.5} & 70 & 239 & -8.4 & -1.5 & & & & \\
\hline & & & & & -22.2 & 0.26 & 22.2 & 92.6 \\
\hline 0.9 & 35 & 390 & -8.1 & -1.5 & & & & \\
\hline 35.7 & 158 & 156 & -7.4 & -1.8 & & & & \\
\hline 45.8 & 74 & 32 & -9.6 & -1.7 & -27.7 & 0.28 & 26.0 & 95.3 \\
\hline \multirow[t]{2}{*}{45.2} & 67 & 41 & -9.2 & -1.5 & -27.8 & 0.66 & 26.3 & 98.0 \\
\hline & & & -10.5 & -1.6 & -25.8 & 0.65 & 24.2 & 96.4 \\
\hline \multirow[t]{4}{*}{3.0} & 99 & 275 & -7.6 & -2.2 & & & & \\
\hline & & & -6.7 & -1.0 & -27.9 & 0.73 & 27.0 & 97.0 \\
\hline & & & -8.9 & -1.1 & & & & \\
\hline & & & -7.8 & -2.1 & -28.6 & 0.84 & 26.5 & 94.8 \\
\hline 35.9 & 96 & 257 & -6.3 & -1.0 & -26.3 & 0.69 & 25.3 & 96.5 \\
\hline \multirow[t]{3}{*}{1.6} & 81 & 335 & -8.0 & -1.3 & -25.4 & 0.38 & 24.1 & 95.4 \\
\hline & & & -6.5 & -0.9 & & & & \\
\hline & & & -7.8 & -0.7 & -24.7 & 3.28 & 24.0 & 99.1 \\
\hline
\end{tabular}


Table A1 (concluded).

\begin{tabular}{|c|c|c|c|c|c|}
\hline Sample No. & Formation & Outcrop/Core & Sample level (m) & Phase & $\mathrm{CaCO}_{3} \%$ \\
\hline WB05 & Watts Bight & Outcrop & 23 & D1 & 60.2 \\
\hline WB04 & Watts Bight & Outcrop & 21.5 & $\mathrm{C} 1$ & 99.1 \\
\hline WB03 & Watts Bight & Outcrop & 18.5 & D1 & \\
\hline WB02 & Watts Bight & Outcrop & 16 & & \\
\hline WB01 & Watts Bight & Outcrop & 14 & D1 & 55.2 \\
\hline WB-A01 & Burry Head & Outcrop & 12 & & \\
\hline WB-A03 & Burry Head & Outcrop & 10 & D2 & 65.5 \\
\hline WB-A04 & Burry Head & Outcrop & 8 & D1 & 62.1 \\
\hline WB-A05 & Burry Head & Outcrop & 6 & D1 & 59.8 \\
\hline WB-A06 & Burry Head & Outcrop & 4.5 & $\mathrm{C} 1$ & 98.3 \\
\hline WB-A07 & Burry Head & Outcrop & 1 & $\mathrm{C} 1$ & \\
\hline WB-A08 (base) & Burry Head & Outcrop & 0.1 & $\mathrm{C} 1$ & 63.7 \\
\hline
\end{tabular}

Note: $\mathrm{C} 1$ and D1 refer to micritic limestone and dolomicrite, respectively. 


\begin{tabular}{|c|c|c|c|c|c|c|c|c|}
\hline $\mathrm{MgCO}_{3} \%$ & $\begin{array}{l}\mathrm{Mn} \\
(\mathrm{ppm})\end{array}$ & $\begin{array}{l}\mathrm{Sr} \\
(\mathrm{ppm})\end{array}$ & $\begin{array}{l}\delta^{18} \mathrm{O} \% \\
\text { VPDB }\end{array}$ & $\begin{array}{l}\delta^{13} \mathrm{C} \text { carbonate } \\
\% \text { VPDB }\end{array}$ & $\begin{array}{l}\delta^{13} \mathrm{C} \text { organic } \\
\% \text { VPDB }\end{array}$ & TOC $\%$ & $\Delta \delta$ & Carbonate $\%$ \\
\hline 39.8 & 50 & 27 & -11.3 & -1.3 & & & & \\
\hline \multirow[t]{3}{*}{0.9} & 42 & 341 & -7.6 & -1.0 & -27.4 & 0.81 & 26.4 & 98.5 \\
\hline & & & -9.3 & -1.2 & & & & \\
\hline & & & & & -25.7 & 1.15 & 25.7 & 97.4 \\
\hline \multirow[t]{2}{*}{44.8} & 54 & 38 & -10.6 & -1.4 & & & & \\
\hline & & & & & -28.2 & 0.65 & 28.2 & 94.9 \\
\hline 34.5 & 130 & 145 & & & -28.2 & 0.83 & 28.2 & 96.1 \\
\hline 37.9 & 82 & 225 & -6.0 & -0.6 & & & & \\
\hline 40.2 & 45 & 142 & -7.8 & -1.1 & -27.6 & 0.54 & 26.6 & 92.0 \\
\hline \multirow[t]{2}{*}{1.7} & 50 & 313 & -7.4 & -1.2 & & & & \\
\hline & & & -7.5 & -1.7 & -28.6 & 0.13 & 26.8 & 46.1 \\
\hline 36.3 & 69 & 175 & -7.5 & -1.1 & & & & \\
\hline
\end{tabular}

